\title{
Radiolabeled $\mathrm{F}\left(\mathrm{ab}^{\prime}\right)_{2}$-cetuximab for theranostic purposes in colorectal and skin tumor-bearing mice models
}

\author{
P.-S. Bellaye ${ }^{1}$ (I) M. Moreau ${ }^{2} \cdot$ O. Raguin ${ }^{3} \cdot$ A. Oudot ${ }^{1} \cdot$ C. Bernhard ${ }^{2} \cdot$ J.-M. Vrigneaud ${ }^{1} \cdot$ L. Dumont $^{4} \cdot$ D. Vandroux ${ }^{4}$.

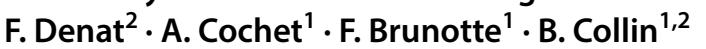

Received: 15 January 2018 / Accepted: 26 April 2018 / Published online: 17 May 2018

(c) The Author(s) 2018

\begin{abstract}
Purpose This study aimed to investigate theranostic strategies in colorectal and skin cancer based on fragments of cetuximab, an anti-EGFR mAb, labeled with radionuclide with imaging and therapeutic properties, ${ }^{111} \mathrm{In}$ and ${ }^{177} \mathrm{Lu}$, respectively. Methods We designed $\mathrm{F}\left(\mathrm{ab}^{\prime}\right)_{2}$-fragments of cetuximab radiolabeled with ${ }^{111} \mathrm{In}$ and ${ }^{177} \mathrm{Lu} .{ }^{111} \mathrm{In}-\mathrm{F}\left(\mathrm{ab}^{\prime}\right)_{2}$-cetuximab tumor targeting and biodistribution were evaluated by SPECT in BalbC nude mice bearing primary colorectal tumors. The efficacy of ${ }^{111} \mathrm{In}-\mathrm{F}\left(\mathrm{ab}^{\prime}\right)_{2}$-cetuximab to assess therapy efficacy was performed on BalbC nude mice bearing colorectal tumors receiving 17-DMAG, an HSP90 inhibitor. Therapeutic efficacy of the radioimmunotherapy based on ${ }^{177} \mathrm{Lu}-\mathrm{F}\left(\mathrm{ab}^{\prime}\right)_{2}$-cetuximab was evaluated in SWISS nude mice bearing A431 tumors.

Results Radiolabeling procedure did not change $\mathrm{F}\left(\mathrm{ab}^{\prime}\right)_{2}$-cetuximab and cetuximab immunoreactivity nor affinity for HER1 in vitro. ${ }^{111}$ In-DOTAGA-F $\left(\mathrm{ab}^{\prime}\right)_{2}$-cetuximab exhibited a peak tumor uptake at $24 \mathrm{~h}$ post-injection and showed a high tumor specificity determined by a significant decrease in tumor uptake after the addition of an excess of unlabeled-DOTAGA$\mathrm{F}\left(\mathrm{ab}^{\prime}\right)_{2}$-cetuximab. SPECT imaging of ${ }^{111} \mathrm{In}$-DOTAGA-F $\left(\mathrm{ab}^{\prime}\right)_{2}$-cetuximab allowed an accurate evaluation of tumor growth and successfully predicted the decrease in tumor growth induced by 17 -DMAG. Finally, ${ }^{177} \mathrm{Lu}-\mathrm{DOTAGA}-\mathrm{F}\left(\mathrm{ab}^{\prime}\right)_{2}$-cetuximab radioimmunotherapy showed a significant reduction of tumor growth at 4 and $8 \mathrm{MBq}$ doses.

Conclusions ${ }^{111} \mathrm{In}$-DOTAGA- $\mathrm{F}\left(\mathrm{ab}^{\prime}\right)_{2}$-cetuximab is a reliable and stable tool for specific in vivo tumor targeting and is suitable for therapy efficacy assessment. ${ }^{177} \mathrm{Lu}$-DOTAGA-F $\left(\mathrm{ab}^{\prime}\right)_{2}$-cetuximab is an interesting theranostic tool allowing therapy and imaging.
\end{abstract}

Keywords Cetuximab fragments $\cdot$ Colorectal cancer $\cdot$ Radioimmunotherapy $\cdot$ EGFR $\cdot$ HSP90

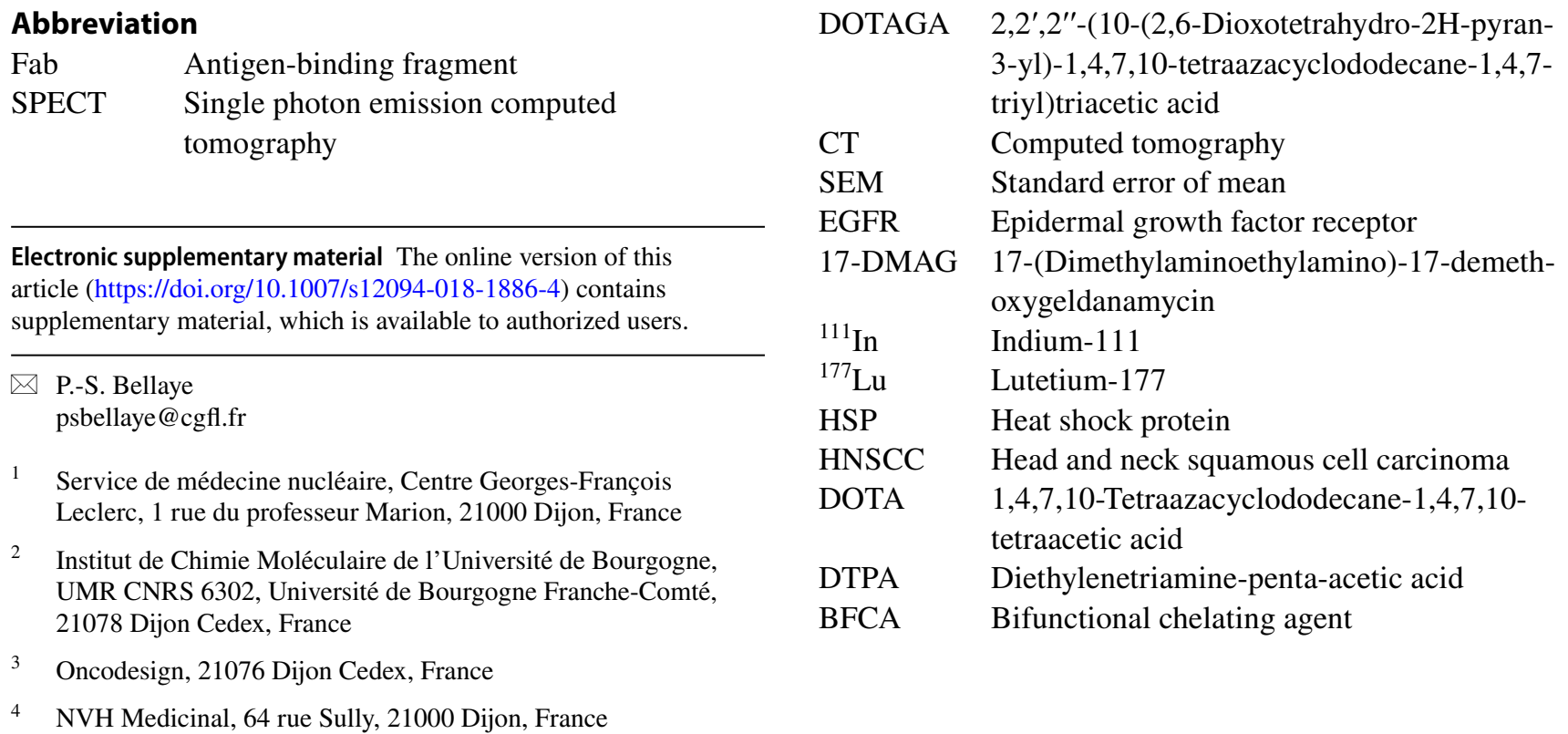




\section{Introduction}

The epidermal growth factor receptor (EGFR) has evolved over the years into a main molecular target for the treatment of different cancer entities. EGFR is a glycosylated transmembrane protein involved in regulating cell growth, differentiation and survival of malignant cells [1]. This receptor is often overexpressed in various malignancies such as head and neck squamous cell carcinoma (HNSCC), gastrointestinal/abdominal carcinoma, lung and reproductive tract carcinomas, melanomas, glioblastomas and thyroid carcinoma [2]. Despite some controversies, the overexpression of EGFR is often associated with a poor clinical prognosis and resistance to radiation therapy [3, 4]. Therefore, therapeutic strategies involving monoclonal antibodies against EGFR, such as cetuximab, have been used pre-clinically and clinically. Cetuximab is a chimeric monoclonal antibody, which binds specifically with a high affinity to the extracellular domain of the EGFR. Cetuximab is used alone or in combination and its therapeutic indications are (i) colorectal and HNSCC and (ii) HNSCC with external radiotherapy [5]. While the combination of cetuximab with radiotherapy showed improved survival [5], tumor response remains heterogeneous and cetuximab failed to show benefit over chemoradiotherapy $[6,7]$. Hence, radioimmunotherapy based on cetuximab labeled with therapeutic radionuclides appears as a promising strategy allowing the delivery of radiation dose specifically to tumor cells expressing high level of EGFR while sparing normal tissues. In this regard, theranostic strategy based on monoclonal antibodies and their deriving structures could represent an exciting approach. This strategy relies on the combination of detection and treatment in one integrated approach [8]. Indeed, it is possible to convert a purely imaging probe into a single-entity theranostic agent by simply switching the radionuclide from a $\gamma$-emitter (e.g.: ${ }^{111} \mathrm{In}$ ) to a $\beta$-emitter (e.g.: ${ }^{90} \mathrm{Y}$ ) or using a radionuclide gathering both imaging and therapeutic properties (e.g.: ${ }^{177} \mathrm{Lu}$ ). We assume that such agents should be safer, more efficient and innovative through their capabilities in sequentially or simultaneously diagnosing, monitoring, and treating disease. The other major theranostic approach relies on the use of a molecular probe to detect and followup a given biomarker during a pharmacotherapy, which is, for example, commonly performed in clinical routine with ${ }^{18} \mathrm{~F}-\mathrm{FDG}$ and PET in oncology [8]. The relevance of using cetuximab radiolabeled with ${ }^{111}$ In in diagnostic imaging has been demonstrated in several animal models mainly due to its high tumor targeting property and its adequate half-life [9-12]. ${ }^{177} \mathrm{Lu}$ is a theranostic radionuclide of choice to target small tumors or metastatic deposits due to the medium energy of the emitted beta particles and their tissue penetration of $1.5 \mathrm{~mm}$. In addition, ${ }^{177} \mathrm{Lu}$ emits $\gamma$-rays which allow diagnostic imaging. The therapeutic efficacy of cetuximab radiolabeled with ${ }^{177} \mathrm{Lu}$ has been demonstrated on various tumor types [13-16].

A major concern with the use of a $\beta$-emitter such as ${ }^{177} \mathrm{Lu}$ as radionuclide is the selection of a chelating agent that forms a sufficiently stable complex to prevent in vivo loss of the radiometal. This choice is crucial to avoid toxicity induced by the delivery of undesired amount of radiation mainly to the radio sensitive bone marrow. Several bifunctional chelating agents (BFCA) have been used for the radiolabeling of cetuximab including DTPA and DOTA derivatives. Several reports highlight the higher in vitro and in vivo stability of DOTA conjugates to sequester ${ }^{111} \mathrm{In}$, ${ }^{177} \mathrm{Lu}$ but also ${ }^{90} \mathrm{Y}$, resulting in lower bone incorporation and marrow toxicity $[14,17-21]$. Our lab previously made the proof of concept that trastuzumab and cetuximab radiolabeled with ${ }^{111}$ In through our new bifunctional chelating agent DOTAGA anhydride [22], were able to bind to their target both in vitro and in vivo [23]. Nevertheless, full-sized antibodies (about $150 \mathrm{kDa}$ ) need to overcome some obstacles before penetrating into a tumor. Indeed, tumor penetration can be hampered by some physiological barriers, such as high interstitial pressure and a "binding site barrier" [24, 25]. To circumvent these drawbacks, it is possible to generate fragments [Fab and $\mathrm{F}\left(\mathrm{ab}^{\prime}\right)_{2}$ ] of the monoclonal antibody to improve its penetration within the tumor. These fragments can be prepared through enzymatic cleavages [papain for $\mathrm{Fab}$ and pepsin for $\mathrm{F}\left(\mathrm{ab}^{\prime}\right)_{2}$ ] or by genetic engineering. Given their pharmacokinetic properties, $\mathrm{F}\left(\mathrm{ab}^{\prime}\right)_{2}(110 \mathrm{kDa})$ could be valuable theranostic agents. Indeed, they are bivalent as the native monoclonal antibody but they are less immunogenic, show a shorter blood clearance, higher tumor-to-background ratios and reduced non-specific distribution [26].

In the present work, our aims were to design $\mathrm{F}\left(\mathrm{ab}^{\prime}\right)_{2^{-}}$ cetuximab-based theranostic agents with both diagnostic and therapeutic capabilities and to assess them in murine preclinical cancer models. First, we characterized in vitro the $\mathrm{F}\left(\mathrm{ab}^{\prime}\right)_{2}$ fragment of cetuximab radiolabeled with ${ }^{111}$ Indium $\left({ }^{111}\right.$ In-DOTAGA-F $\left(\mathrm{ab}^{\prime}\right)_{2}$-cetuximab) in comparison with whole cetuximab used as a reference $\left({ }^{111}\right.$ In-DOTAGAcetuximab). Then, we evaluated the stability of DTPA- and DOTAGA-radiolabeled $\mathrm{F}\left(\mathrm{ab}^{\prime}\right)_{2}$-cetuximab. We made the proof of concept that ${ }^{111} \mathrm{In}$-DOTAGA-F $\left(\mathrm{ab}^{\prime}\right)_{2}$-cetuximab was suitable for monitoring the down-regulation of EGFR as a biomarker of the efficacy of a targeted therapy with a HSP90 inhibitor. In cancer cells, the stability of EGFR is promoted by the chaperon protein HSP90 [27]. The chemical inhibition of HSP90 leads to an increase in EGFR degradation hampering oncologic signaling pathways [27]. Finally, we designed a strategy based on radioisotopic switching to perform radioimmunoscintigraphy $\left({ }^{111} \mathrm{In}\right.$-DOTAGA$\mathrm{F}\left(\mathrm{ab}^{\prime}\right)_{2}$-cetuximab) prior to radioimmunotherapy 
$\left({ }^{177}\right.$ Lu-DOTAGA-F $\left(\mathrm{ab}^{\prime}\right)_{2}$-cetuximab) in colorectal tumorbearing mice. ${ }^{177}$ Lu-DOTAGA-F $\left(\mathrm{ab}^{\prime}\right)_{2}$-cetuximab showed a good tolerance and efficacy for reducing tumor volume in our model.

\section{Materials and methods}

Detailed Materials and methods are available in Supplemental materials.

\section{Preparation of cetuximab and $F\left(a b^{\prime}\right)_{2}$ fragments}

$\mathrm{F}\left(\mathrm{ab}^{\prime}\right)_{2}$ fragment was prepared by dialysis of $15 \mathrm{~mL}$ of cetuximab at $5 \mathrm{mg} \cdot \mathrm{mL}^{-1}$ against pepsin buffer (sodium acetate $20 \mathrm{mM} /$ acetic acid pH4) on $10 \mathrm{kDa}$ cut off (Amicon Ultra 15 -Millipore) using centrifugation (4000 $\mathrm{g} ; 2 \times 20 \mathrm{~min})$. See details in Supplemental methods.

\section{Derivatization of cetuximab and $F\left(a b^{\prime}\right)_{2}$ fragments for radiolabeling}

\section{Conjugation of DOTAGA anhydride with cetuximab}

Conjugation was performed at a 20:1 DOTAGA-anhydride/ cetuximab molar ratio. $100 \mu \mathrm{L}$ of a $3.7 \mathrm{mg} \cdot \mathrm{mL}^{-1}$ suspension of DOTAGA-anhydride ( $370 \mu \mathrm{g}, 0.8 \mu \mathrm{mol}, 20$ equiv) in dry chloroform (Carlo Erba, Val de Reuil, France) were pipetted under ultrasonication and transferred into a $15 \mathrm{~mL}$ polypropylene tube. The chloroform was evaporated under a gentle stream of air. $480 \mu \mathrm{L}$ of a solution of purified cetuximab (12.5 mg. $\mathrm{mL}^{-1}, 6 \mathrm{mg}, 40 \mathrm{nmol}, 1$ equiv) in PBS, $\mathrm{pH}$ 7.4, (Fisher Scientific, Illkirch, France) were subsequently added. The solution was completed to $3 \mathrm{~mL}$ with PBS $0.1 \mathrm{M}$, $\mathrm{pH} 7.4$, and gently mixed at $25{ }^{\circ} \mathrm{C}$ for $30 \mathrm{~min}$. Unbound DOTAGA was then removed by ultrafiltration (Vivaspin filter $10 \mathrm{kDa}$, Sartorius, $30 \mathrm{~min}$ at $1520 \mathrm{~g}, 4^{\circ} \mathrm{C}$ ). Conjugated cetuximab was washed twice with $5 \mathrm{~mL}$ of PBS $0.1 \mathrm{M}, \mathrm{pH}$ 7.4 , and the concentrated solution was diluted in $500 \mu \mathrm{L}$ of ammonium acetate buffer $0.1 \mathrm{M}$ pH 5.9. The purified immunoconjugate DOTAGA-cetuximab was stored at $4{ }^{\circ} \mathrm{C}$. Concentration of the antibody was determined by UV spectrophotometry at $280 \mathrm{~nm}\left(E_{280}=1.44 \mathrm{mg} \mathrm{mL}^{-1} \mathrm{~cm}^{-1}\right)$. The degree of labeling was determined by MALDI-TOF mass spectrometry using sinapinic acid as matrix.

\section{Conjugation of DOTAGA anhydride to $F\left(a b^{\prime}\right)_{2}$-cetuximab}

Following a similar procedure, conjugation was performed at a 15:1 DOTAGA-anhydride/F $\left(\mathrm{ab}^{\prime}\right)_{2}$ molar ratio. $111 \mu \mathrm{L}$ of a $3.7 \mathrm{mg} . \mathrm{mL}^{-1}$ suspension of DOTAGA-anhydride $(411 \mu \mathrm{g}$, $0.9 \mu \mathrm{mol}, 15$ equiv) in dry chloroform were pipetted under ultrasonication and transferred into a $15 \mathrm{~mL}$ polypropylene tube. See details in Supplemental methods.

\section{${ }^{111}$ In and ${ }^{177}$ Lu radiolabeling procedures}

\section{General procedure for radiolabeling for in vitro studies}

$7.5 \mathrm{MBq}$ of ${ }^{111} \mathrm{InCl}_{3}$ (Perkin Elmer) were added to $50 \mu \mathrm{g}$ of the immunoconjugate in $0.1 \mathrm{M}$ ammonium acetate buffer, $\mathrm{pH} 5.9$, to reach a buffer/ $\mathrm{HCl}$ (from ${ }^{111} \mathrm{InCl}_{3}$ solution) ratio of 1.5:1 resulting in a pH 5 solution. See details in Supplemental methods.

\section{General procedure for radiolabeling for in vivo studies}

${ }^{111} \mathrm{InCl}_{3}$ or ${ }^{177} \mathrm{LuCl}_{3}$ (Perkin Elmer) were buffered with 1/10th (v/v) of $1 \mathrm{M}$ ammonium acetate solution $\mathrm{pH} 7.1$ and then added to DOTAGA- $\mathrm{F}\left(\mathrm{ab}^{\prime}\right)_{2}$ in $0.1 \mathrm{M}$ ammonium acetate buffer pH 5.9 (600 MBq mg ${ }^{-1}$ and 1 GBq. $\mathrm{mg}^{-1}$, respectively). See details in Supplemental methods.

\section{Stability assay}

${ }^{111}$ In-DOTAGA-F $\left(\mathrm{ab}^{\prime}\right)_{2}$-cetuximab/ $/{ }^{111}$ In-DTPA-F $\left(\mathrm{ab}^{\prime}\right)_{2}{ }^{-}$ cetuximab stability in EDTA and plasma were evaluated up to 7 days. See details in Supplemental methods.

\section{Cell culture}

Epidermoid carcinoma cells A431 (ATCC, Rockville, MD) overexpressing the HER1 antigen at their surface [28] and primary human tumor fragments from colon tumor (CRLRB-014P) have been used. CR-LRB-014P cells have been collected from a biopsy of a primitive colorectal tumor from a 70-year-old male in 2008 in the hospital center of "Lariboisière", Paris, France (no treatment before surgery). See details in Supplemental methods.

\section{Determination of ${ }^{111}$ In-DOTAGA-cetuximab and ${ }^{111}$ In-DOTAGA-F $\left(a b^{\prime}\right)_{2}$-cetuximab binding affinity and immunoreactivity}

\section{Immunoreactivity}

The fraction of ${ }^{111}$ In-DOTAGA-F $\left(\mathrm{ab}^{\prime}\right)_{2}$-cetuximab and ${ }^{111}$ In-DOTAGA-cetuximab able to bind to HER1 was determined by incubating trace amounts of ${ }^{111}$ In-DOTAGA$\mathrm{F}\left(\mathrm{ab}^{\prime}\right)_{2}$-cetuximab or ${ }^{111}$ In-DOTAGA-cetuximab (1 MBq, $\left.7.0 \times 10^{-9} \mathrm{M}\right)$ with increasing concentrations of HER 1 expressing cell A431 $\left(0.4-24 \times 10^{6}\right.$ cells $\left.\mathrm{mL}^{-1}\right)$ in a total volume of $0.2 \mathrm{~mL}$ for $1 \mathrm{~h}$ at $4{ }^{\circ} \mathrm{C}$. See details in Supplemental methods. 


\section{Binding affinity}

The affinity constants $(\mathrm{Kd})$ of the ${ }^{111}$ In-DOTAGA-F $\left(a b^{\prime}\right)_{2}$ cetuximab and ${ }^{111}$ In-DOTAGA-cetuximab were determined in radioligand binding saturation assays. Approximately $3 \times 10^{5}$ A431 cells were incubated with increasing concentrations of ${ }^{111}$ In-DOTAGA-F $\left(\mathrm{ab}^{\prime}\right)_{2}$-cetuximab or ${ }^{111}$ In-DOTAGA-cetuximab $\left(5.3 \times 10^{-11}\right.$ to $5.4 \times 10^{-8} \mathrm{M}$, $100 \mathrm{MBq} \cdot \mathrm{mg}^{-1}$ ) in a total volume of $0.2 \mathrm{~mL}$ for $1 \mathrm{~h}$ at $4{ }^{\circ} \mathrm{C}$. See details in Supplemental methods.

\section{Animal models}

All animal experiments were performed according to the guidelines of the Ministère de la Recherche (Paris, France). All experiments were approved by the ethical committee of the "Centre Georges-François Leclerc" (Dijon, France).

\section{Biodistribution study}

\section{SPECT/CT imaging protocol and $\gamma$-counting}

Female Balb/c nu/nu mice $(n=3,6-8$ weeks old, purchased from Charles River, France) were grafted by subcutaneous injection of colon tumor fragments from human patients (CR-LRB-014P). When grown these tumors were collected and fragments from these tumors were implanted into a second set of Balb/c nu/nu mice (6-8 weeks old). 3 or 5 weeks after tumor implantation, tumor-bearing mice were given $25 \mu \mathrm{g}{ }^{111}$ In-DOTAGA-F $\left(\mathrm{ab}^{\prime}\right)_{2}$-cetuximab (13-15 MBq) by intravenous injection. In a second experiment to assess the specificity of the targeting in vivo, a group of mice received $25 \mu \mathrm{g}{ }^{111} \mathrm{In}$-DOTAGA-F $\left(\mathrm{ab}^{\prime}\right)_{2}$-cetuximab (3-3.5 MBq) in co-injection with excess $(2500 \mu \mathrm{g})$ cold-F $\left(\mathrm{ab}^{\prime}\right)_{2^{-}}$ cetuximab. Two groups of mice were then studied: (1) ${ }^{111}$ In-DOTAGA-F $\left(\mathrm{ab}^{\prime}\right)_{2}$-cetuximab and (2) ${ }^{111}$ In-DOTAGA$\mathrm{F}\left(\mathrm{ab}^{\prime}\right)_{2}$-cetuximab + non radiolabelled-DOTAGA-F $\left(\mathrm{ab}^{\prime}\right)_{2}{ }^{-}$ cetuximab. SPECT/CT dual imaging was performed 3, 6 , $20,24,48$, and $72 \mathrm{~h}$ after the injection of the radiolabeled conjugate using a NanoSPECT/CT small animal imaging tomographic $\gamma$-camera (Bioscan Inc., Washington, DC). Mice were anaesthetized with isoflurane (1.5-3\% in air) and positioned in a dedicated cradle. CT and SPECT acquisitions were performed in immediate sequence. CT acquisitions (55 kVp, $34 \mathrm{mAs}$ ) were first acquired during 15-20 min, followed by helical SPECT acquisitions with $90-120 \mathrm{~s}$ per projection frame resulting in acquisition times of 45-60 min. Both indium-111 photopeaks (171 and $245 \mathrm{keV}$ ) were used with $10 \%$ wide energy windows. After the last image acquisition, animals were euthanized. Blood, tumor, and organs were collected, and radioactivity was measured with a scintillation $\gamma$-counter. Data were then converted to percentage of injected dose and to percentage of injected dose per $\mathrm{mm}^{3}$ of tissue. The CT and SPECT reconstructions were performed using image processing software provided by Bioscan Inc. Eventually, the SPECT/CT fusion image was obtained using the InVivoScope software (Bioscan Inc.). Each scan was then visually interpreted, and 3D regions of interest corresponding to the tumor and whole body were manually drawn to determine their radioactivity content. In vivo quantification was obtained by accurate calibration of the NanoSPECT/CT $\gamma$-camera. Radioactivity contents from image analysis were expressed in $\mathrm{Bq} / \mathrm{mm}^{3}$, converted to percentage of injected dose, and compared to those determined by ex vivo counting.

\section{Therapy evaluation study}

\section{${ }^{111}$ In-DOTAGA-F $\left(a^{\prime}{ }^{\prime}\right)_{2}$-cetuximab to evaluate HSP90 inhibition}

Female Balb/c nu/nu mice ( $n=10,6-8$ weeks old) were grafted by subcutaneous injection of colon tumor fragments from human patients. When grown these tumors were collected and fragments from these tumors were implanted into a second set of Balb/c nu/nu mice (6-8 weeks old). Tumor volume was measured three times a week from D30 to D50 after cells injection. Mice were randomized in two groups with (1) mice receiving i.p. 17-DMAG (17-DMAG group, $25 \mathrm{mg} / \mathrm{kg}$ ) or (2) vehicle (vehicle group) three times a week from D30. ${ }^{111} \mathrm{In}-\mathrm{F}\left(\mathrm{ab}^{\prime}\right)_{2}$-cetuximab tumor uptake (iv. injection) was evaluated every week from D30 using SPECT-CT imaging (20-25 $\mu \mathrm{g}, 10 \mathrm{MBq}$, imaging $24 \mathrm{~h}$ after injection) as described above (D38, D44, D51 and D58).

\section{Targeted radioimmunotherapy study}

\section{Dose escalation of ${ }^{177}$ Lu-DOTAGA-F $\left(\mathrm{ab}^{\prime}\right)_{2}$-cetuximab in vivo}

Under isoflurane anesthesia, female SWISS nu/nu mice $(n=4)$ were grafted by subcutaneous injection in the flank with $2 \times 10^{7}$ A431 cells. Tumor volume was measured three times a week from D3 after administration. At D14 after tumor cell injection, mice were randomized into four groups with (1) mice receiving vehicle (vehicle group), (2) mice receiving ${ }^{177} \mathrm{Lu}$-DOTAGA-F $\left(\mathrm{ab}^{\prime}\right)_{2}$-cetuximab at $2 \mathrm{MBq}$ (2 MBq group), (3) mice receiving ${ }^{177}$ Lu-DOTAGA-F $\left(a b^{\prime}\right)_{2}-$ cetuximab at $4 \mathrm{MBq}$ (4 MBq group) and (4) mice receiving ${ }^{177} \mathrm{Lu}$-DOTAGA- $\mathrm{F}\left(\mathrm{ab}^{\prime}\right)_{2}$-cetuximab at $8 \mathrm{MBq}(8 \mathrm{MBq}$ group). ${ }^{177} \mathrm{Lu}$-DOTAGA-F $\left(\mathrm{ab}^{\prime}\right)_{2}$-cetuximab was injected i.v. (vehicle, $2 \mathrm{MBq}, 4 \mathrm{MBq}$ or $8 \mathrm{MBq} / \mathrm{mouse}$ ). SPECT-CT imaging was performed $24 \mathrm{~h}$ after i.v. injection as described above to assess tumor targeting. Tumor volume was then assessed three times a week up to D23. Weight loss of animals was monitored throughout the experiments. 


\section{Statistical analysis}

All results are presented as mean \pm SEM. A $p$ value less than 0.05 was considered significant. See details in Supplemental methods.

\section{Results}

\section{DOTAGA-cetuximab and DOTAGA-F $\left(a b^{\prime}\right)_{2}$-cetuximab retain their immunoreactivity and affinity for HER1}

We first evaluated the production and purification of $\mathrm{F}\left(\mathrm{ab}^{\prime}\right)_{2}$ cetuximab by western blotting (Fig. 1a). As expected, dialysis did not disrupt the integrity of cetuximab and dialyzed and non-dialyzed cetuximab whole antibodies presented a similar profile with a molecular weight above $170 \mathrm{kDa}$. Pepsin digestion of cetuximab was almost complete with a large band corresponding to the size of $\mathrm{F}\left(\mathrm{ab}^{\prime}\right)_{2}$ fragment near $110-120 \mathrm{kDa}$ and only a light band remaining at $170 \mathrm{kDa}$. After purification on the two columns and dialysis (yield: $40 \%$ ), the residual whole antibody was fully eliminated with a purity of $\mathrm{F}\left(\mathrm{ab}^{\prime}\right)_{2}$-cetuximab greater than $95 \%$ (Fig. 1a). Once purified, cetuximab and $\mathrm{F}\left(\mathrm{ab}^{\prime}\right)_{2}$-cetuximab were placed with a 20- or 15-fold excess of DOTAGAanhydride for $30 \mathrm{~min}$ at $25{ }^{\circ} \mathrm{C}$ resulting in conjugation of 3.7 and 3.1 DOTAGA chelators per molecule, respectively. The labeling efficiencies measured by ITLC for ${ }^{111} \mathrm{In}$ DOTAGA-cetuximab, ${ }^{111}$ In-DOTAGA-F $\left(\mathrm{ab}^{\prime}\right)_{2}$-cetuximab, and ${ }^{177} \mathrm{Lu}$-DOTAGA-F $\left(\mathrm{ab}^{\prime}\right)_{2}$-cetuximab were above $98 \%$ (data not shown). The ability of both forms of cetuximab to bind to HER1 was then evaluated by FACS on A431 cells which express this receptor (Fig. 1b). Interestingly, a shift in cell-associated fluorescence was observed by FACS with DOTAGA-cetuximab and DOTAGA-F $\left(\mathrm{ab}^{\prime}\right)_{2}$-cetuximab comparable with cetuximab and $\mathrm{F}\left(\mathrm{ab}^{\prime}\right)_{2}$-cetuximab alone, respectively (Fig. 1b). Thus, the binding of DOTAGA on both forms of cetuximab did not disturb its binding ability on HER1. To confirm these results, the immunoreactivity and affinity of DOTAGA-cetuximab and DOTAGA-F $\left(\mathrm{ab}^{\prime}\right)_{2}$ cetuximab have been evaluated on A431 cells. ${ }^{111} \mathrm{In}$-DOTAGA-cetuximab and ${ }^{111}$ In-DOTAGA-F $\left(\mathrm{ab}^{\prime}\right)_{2}$-cetuximab have similar immunoreactivity around $50 \%$ (Fig. 1c). Moreover, the affinity of ${ }^{111}$ In-DOTAGA-cetuximab was evaluated at $1.7 \mathrm{nM}$ and the affinity of ${ }^{111} \mathrm{In}$-DOTAGA-F $\left(\mathrm{ab}^{\prime}\right)_{2}{ }^{-}$ cetuximab was $0.9 \mathrm{nM}$ (Fig. 1d). These affinities values were compatible with in vivo use of radioimmunoconjugates. Finally, DOTAGA-F $\left(\mathrm{ab}^{\prime}\right)_{2}$-cetuximab was used for our in vivo experiments. All together these results demonstrate that $\mathrm{F}\left(\mathrm{ab}^{\prime}\right)_{2}$ fragments of cetuximab retain their immunoreactivity and affinity for HER1 which are not disturbed by DOTAGA incorporation.
DOTAGA conjugates show much higher stability than DTPA conjugates

${ }^{111}$ In-DOTAGA-F $\left(\mathrm{ab}^{\prime}\right)_{2}$-cetuximab and ${ }^{111}$ In-DTPA-F $\left(\mathrm{ab}^{\prime}\right)_{2}{ }_{2}$ cetuximab stability toward EDTA and human plasma was evaluated on 7 days. The stability of ${ }^{111}$ In-DOTAGA-F $\left(\mathrm{ab}^{\prime}\right)_{2^{-}}$ cetuximab was greater than ${ }^{111}$ In-DTPA-F $\left(a b^{\prime}\right)_{2}$-cetuximab in both conditions with a $100 \%$ of ${ }^{111}$ In still incorporated up to D7. ${ }^{111}$ In-DTPA-F $\left(\mathrm{ab}^{\prime}\right)_{2}$-cetuximab stability was significantly lower with only 45 and $48 \%$ of ${ }^{111}$ In still incorporated at D7 in EDTA and plasma, respectively (Fig. 1d).

In vivo tumor specificity of ${ }^{111}$ InDOTAGA-F $\left(\mathrm{ab}^{\prime}\right)_{2}$-cetuximab

${ }^{111}$ In-DOTAGA-F $\left(\mathrm{ab}^{\prime}\right)_{2}$-cetuximab biodistribution was evaluated in Balb/c nude mice grafted subcutaneously with CR-LRB-014P human colon tumor fragments at 3, 6, 20, 24, 48 and $72 \mathrm{~h}$ post injection. Liver and kidney were the normal tissues with highest uptake (Fig. 2a). The liver uptake remained stable from 3 to $24 \mathrm{~h}$ post injection. Then, it started to significantly decrease at 48 and $72 \mathrm{~h}$ post injection. The kidney uptake significantly increased at 20 and $24 \mathrm{~h}$ compared to $3 \mathrm{~h}$ post injection and remained stable up to $72 \mathrm{~h}$ post injection. The bladder uptake remained stable throughout the experiment (Fig. 2a). Interestingly, the tumor uptake started to significantly increase at $20 \mathrm{~h}$ post injection and remained increased up to $72 \mathrm{~h}$ compared to $3 \mathrm{~h}$ post injection (Fig. 2a, b). Mice that were pre-injected with an excess of unlabeled $F\left(a b^{\prime}\right)_{2}$-cetuximab had significantly lower tumor uptake demonstrating the specificity of $\mathrm{F}\left(\mathrm{ab}^{\prime}\right)_{2}$-cetuximab for the CR-LRB-014P tumors (Fig. 2c).

\section{${ }^{111}$ In-DOTAGA-F $\left(\mathrm{ab}^{\prime}\right)_{2}$-cetuximab is a reliable tool to monitor 17-DMAG treatment efficacy}

Balb/c nude mice grafted subcutaneously with human primary colon tumor fragments (CR-LRB-014P) received 17-DMAG three times a week from D30 up to D58. Weight loss and tumor growth were monitored throughout the experiment. Mice received ${ }^{111} \mathrm{In}-\mathrm{F}\left(\mathrm{ab}^{\prime}\right)_{2}$-cetuximab every week from D30 (D38, D44, D51 and D58) for SPECT-CT imaging (imaging $24 \mathrm{~h}$ after injection). 17-DMAG induced a slight weight loss from D42 (12 days after treatment start) that was partially recovered by D58 compared to mice receiving vehicle (Fig. 3a). Interestingly, 17-DMAG induced a significant decrease in tumor growth compared to vehicle from D44 up to D58 (Fig. 3b). In parallel, tumor uptake of ${ }^{111} \mathrm{In}-\mathrm{F}\left(\mathrm{ab}^{\prime}\right)_{2^{-}}$ cetuximab measured by SPECT-CT imaging demonstrated that 17-DMAG treatment reduced tumor uptake compared to vehicle. Although only significant from D58, a marked reduced tumor uptake was observed from D44 ( $p=0.059$, 

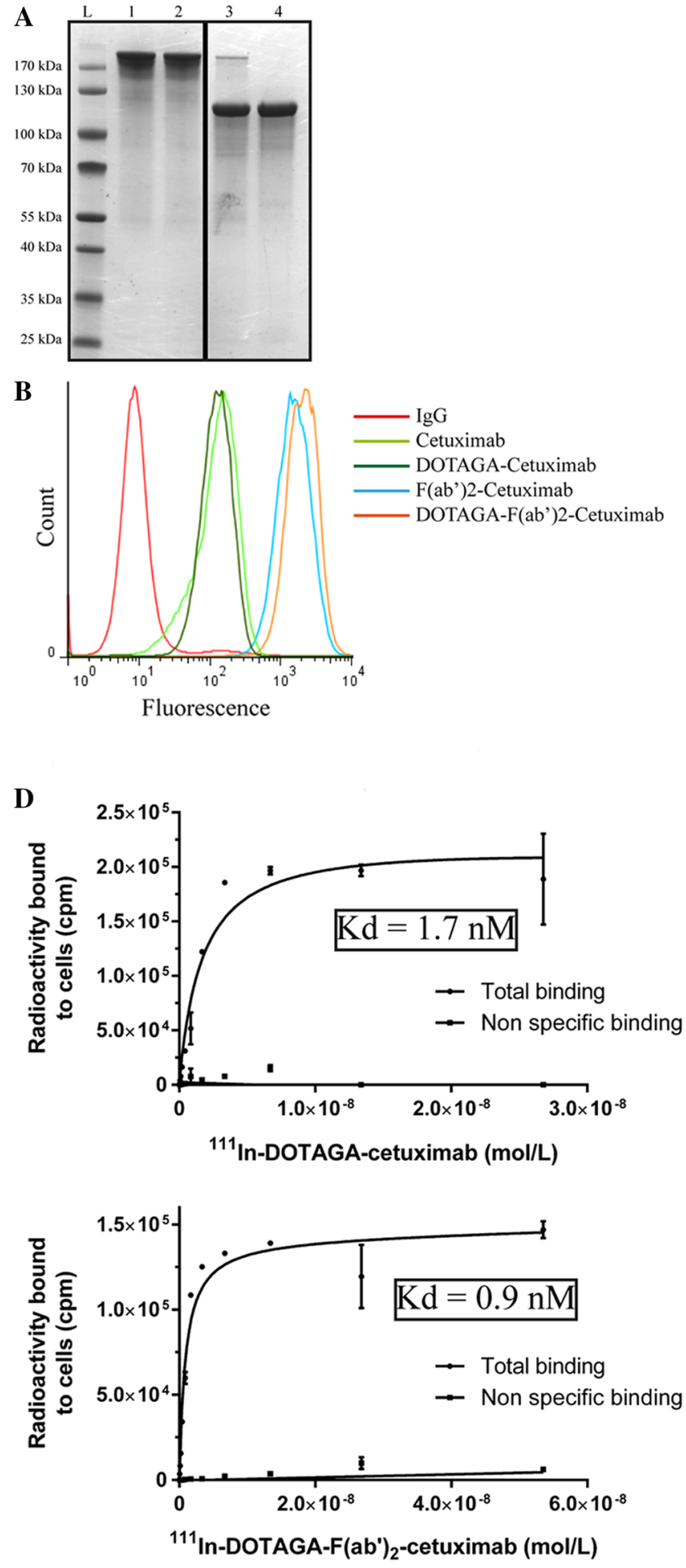

Fig. 3c). Interestingly, tumor volume measured by SPECTCT imaging reflected the decrease in tumor growth induced by 17-DMAG observed by manual measurements (Fig. 3d-f). However, a significant difference in tumor volume measured by SPECT-CT between 17-DMAG and vehicle was only observed at D51 while already observed at D44
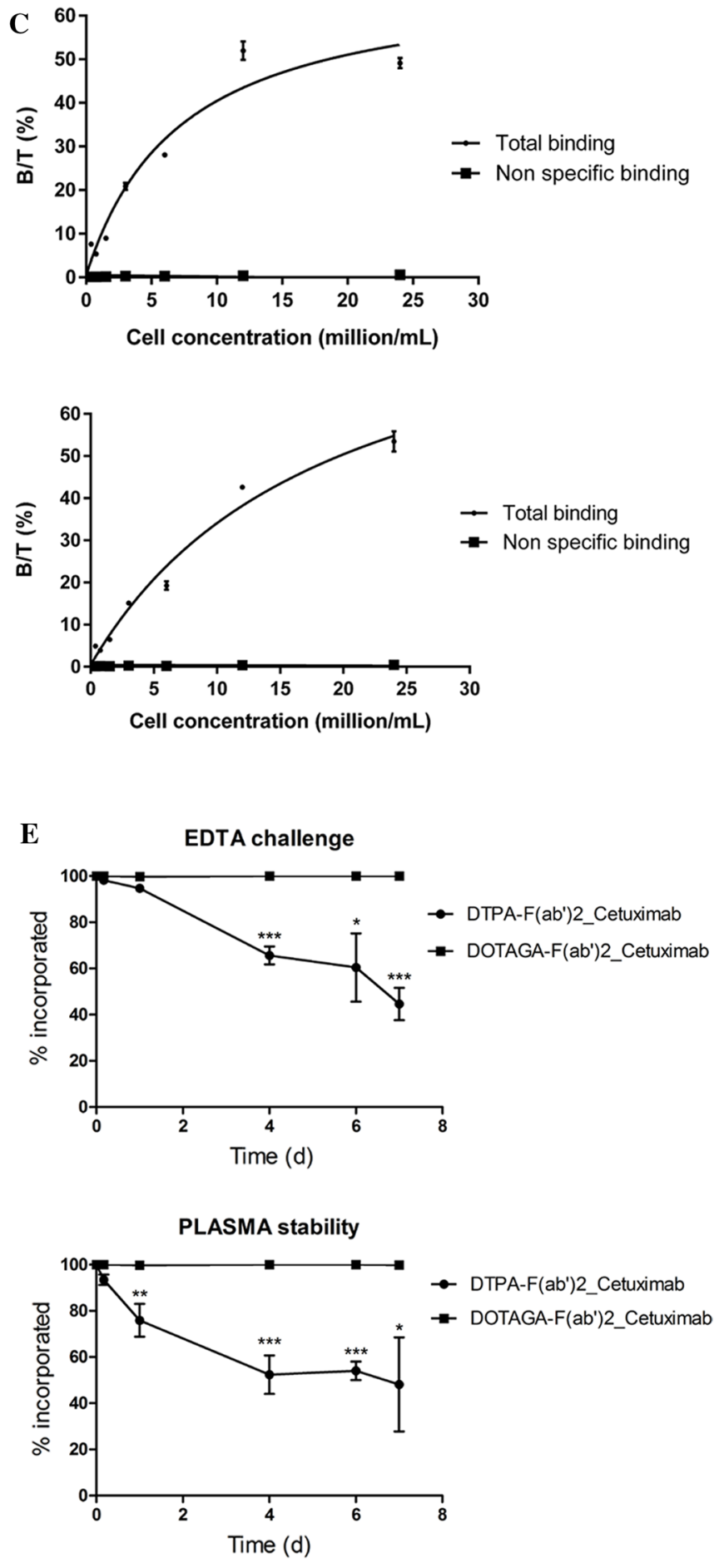

by manual measurements (Fig. 3d). However, the decrease in tumor volume measured by SPECT-CT was clearly observed from D44 even though not significant $(p=0.065)$. Interestingly, there was a strong positive correlation between tumor volumes measured manually and with SPECT/CT imaging (Fig. 3e). All together these results confirm that 17-DMAG 
४Fig. 1 DOTAGA-cetuximab and DOTAGA-F( $\left(\mathrm{ab}^{\prime}\right)_{2}$-cetuximab retain their immunoreactivity and affinity for HER1. a 4-12\% bis-tris acrylamide gel stained with coomassie blue performed on $5 \mu \mathrm{g}$ of whole cetuximab (1), whole cetuximab after dialysis (2), $\mathrm{F}\left(\mathrm{ab}^{\prime}\right)_{2}$ fragments after digestion $\left(8 \mathrm{~h}\right.$ at $\left.37{ }^{\circ} \mathrm{C}\right)(3)$ and $\mathrm{F}\left(\mathrm{ab}^{\prime}\right)_{2}$ fragments after purification on protein A and $L$ columns and dialysis (4). $L=$ Protein Ladder. b FACS analysis of A431 fluorescence incubated with cetuximab (light green), DOTAGA-cetuximab (dark green), F( $\left(\mathrm{bb}^{\prime}\right)_{2}$ cetuximab (light blue), DOTAGA-F $\left(\mathrm{ab}^{\prime}\right)_{2}$-cetuximab (orange). Non-relevant IgG served as control. c Immunoreactivity assay of ${ }^{111}$ In-DOTAGA-cetuximab (higher panel) and ${ }^{111}$ In-DOTAGA$\mathrm{F}\left(\mathrm{ab}^{\prime}\right)_{2}$-cetuximab (lower panel). $1 \mathrm{MBq}$ of ${ }^{111}$ In-DOTAGA-cetuximab or ${ }^{111}$ In-DOTAGA-F $\left(\mathrm{ab}^{\prime}\right)_{2}$-cetuximab were incubated with increasing concentration of A431 cells $\left(0.4-24 \times 10^{6}\right)$. The radioactivity associated to cells (bound radioactivity, B) and an aliquot of the supernatant (total radioactivity, $\mathrm{T}$ ) to calculate the bound-to-total ratios $(\mathrm{B} / \mathrm{T}$, expressed in \%). Nonspecific binding was evaluated in the presence of $a>100$-fold excess unlabeled cetuximab or $\mathrm{F}\left(\mathrm{ab}^{\prime}\right)_{2^{-}}$ cetuximab. Immunoreactivity was defined as the highest $\mathrm{B} / \mathrm{T} \%$ ratio that could be reached. Results are presented as mean \pm SEM, $n=3$. d Binding affinity assay of ${ }^{111}$ In-DOTAGA-cetuximab (higher panel) and ${ }^{111}$ In-DOTAGA-F $\left(\mathrm{ab}^{\prime}\right)_{2}$-cetuximab (lower panel). $3 \times 10^{5}$ A431 cells were incubated with increasing concentrations of ${ }^{111}$ In-DOTAGA-F $\left(\mathrm{ab}^{\prime}\right)_{2}$-cetuximab or ${ }^{111}$ In-DOTAGA-cetuximab $\left(5.3 \times 10^{-11}-5.4 \times 10^{-8} \mathrm{M}, 100 \mathrm{MBq} \cdot \mathrm{mg}^{-1}\right)$. Radioactivity associated to cells was counted with a scintillation $\gamma$-counter. Nonspecific binding was evaluated in the presence of $a>100$-fold excess unlabeled DOTAGA-F $\left(\mathrm{ab}^{\prime}\right)_{2}$-cetuximab or DOTAGA-cetuximab. Results are presented as mean $\pm \mathrm{SEM}, n=3$. e. EDTA (upper panel) and plasma (lower panel) stability of ${ }^{111}$ In-DOTAGA-F $\left(\mathrm{ab}^{\prime}\right)_{2}$-cetuximab and ${ }^{111}$ In-DTPA-F $\left(\mathrm{ab}^{\prime}\right)_{2}$-cetuximab from D0 up to D7. Graphs represent $\%$ of ${ }^{111} \mathrm{In}$ still incorporated in each bioconjugate. Results are presented as mean $\pm \mathrm{SEM}, n=3$

prevents tumor growth in our model of CR-LRB-014P tumors. The effectiveness of 17-DMAG can be accurately measured by SPECT-CT imaging of ${ }^{111} \mathrm{In}-\mathrm{F}\left(\mathrm{ab}^{\prime}\right)_{2}$-cetuximab tumor uptake and corresponding tumor volume.

\section{${ }^{177}$ Lu-DOTAGA-F $\left(a b^{\prime}\right)_{2}$-cetuximab prevents tumor growth in vivo}

SWISS nude mice grafted subcutaneously with A431 cells received a single injection of ${ }^{177} \mathrm{Lu}$ - DOTAGA-F $\left(\mathrm{ab}^{\prime}\right)_{2^{-}}$ cetuximab (iv, 2, 4 or $8 \mathrm{MBq}$ ) on D14 after tumor inoculation. Control mice received vehicle on D14 (iv). While both $2 \mathrm{MBq}$ and $8 \mathrm{MBq}$ of ${ }^{177} \mathrm{Lu}$-DOTAGA-F $\left(\mathrm{ab}^{\prime}\right)_{2}$ cetuximab did not induce weight loss in treated animals, $4 \mathrm{MBq}$ induced a rapid weight loss at D20 which was normalized by D23 (Fig. 4a). Interestingly, all three doses of ${ }^{177}$ Lu-DOTAGA-F $\left(\mathrm{ab}^{\prime}\right)_{2}$-cetuximab induced a reduction of tumor growth between D14 and D20 although only significant in mice receiving 4 and $8 \mathrm{MBq}$ of ${ }^{177} \mathrm{Lu}$-DOTAGA$\mathrm{F}\left(\mathrm{ab}^{\prime}\right)_{2}$-cetuximab (Fig. 4b, c). Taken together these results demonstrate that ${ }^{177} \mathrm{Lu}$-DOTAGA-F $\left(\mathrm{ab}^{\prime}\right)_{2}$-cetuximab is able to prevent A431 cells' tumor growth with a highest efficacy at 4 and $8 \mathrm{MBq}$.

\section{Discussion}

Colorectal cancer is nowadays the third most commonly diagnosed and the fourth leading cause of cancer-related deaths worldwide [29-31]. Current treatment options offer a limited benefit on survival of patients with stage IV colorectal cancer with a 5 years survival of less than $10 \%$, highlighting the urgent need for innovative therapeutic strategies [31]. Theranostic approaches based on radiolabeled antibodies allow the selective targeting of tumor cell antigens for diagnostic, evaluation of therapy efficacy and delivery of ionizing radiation to tumor sites depending on the chosen radionuclide. The upregulation of EGFR has been reported in colorectal cancer and is associated with poor prognosis and resistance to radiation therapy. Thus, EGFR is nowadays an important target for therapy with anti-EGFR antibodies [32]. Cetuximab is a monoclonal antibody approved for treatment of colorectal cancer which selectively binds EGFR to prevent the binding of natural EGFR-ligands and promote antibodyreceptor complex internalisation [33]. However, the pharmacokinetics of whole cetuximab is slow, due to its size, and ranges from 63 to $230 \mathrm{~h}$ in patients [34]. This slow pharmacokinetics is not optimal for rapid and dynamic EGFR imaging. Moreover, the extended presence of whole cetuximab in the blood often induces misinterpretation of the amount of EGFR. In mice the biological half-life of $\mathrm{F}\left(\mathrm{ab} \mathrm{b}^{\prime}\right)_{2}$ fragments of cetuximab is six times shorter than that of whole cetuximab (12 and $70 \mathrm{~h}$, respectively [35, $36])$. Thus, we designed for the current study $F\left(a b^{\prime}\right)_{2}$ cetuximab radiolabeled with ${ }^{111}$ Indium $\left({ }^{111} \mathrm{In}-\mathrm{F}\left(\mathrm{ab}^{\prime}\right)_{2^{-}}\right.$ cetuximab) which overcomes issues raised with whole cetuximab by displaying fast blood clearance, rapid tumor accumulation and enables earlier molecular imaging [11, 37]. Our results are in accordance with previous studies which report a peak in tumor uptake of $\mathrm{F}\left(\mathrm{ab}^{\prime}\right)_{2}$-cetuximab at $24 \mathrm{~h}$ post injection [36, 37]. Moreover, the immunoreactivity and affinity of ${ }^{111} \mathrm{In}$-DOTAGA-F $\left(\mathrm{ab}^{\prime}\right)_{2}$-cetuximab and ${ }^{111}$ In-DOTAGA-cetuximab found in the current study are also in accordance with the literature. Indeed, Van Dijk et al. [37] reported an immunoreactivity of $\mathrm{F}\left(\mathrm{ab}^{\prime}\right)_{2}-$ cetuximab of $58 \%$ compared to $50 \%$ for ${ }^{111}$ In-DOTAGA$\mathrm{F}\left(\mathrm{ab}^{\prime}\right)_{2}$-cetuximab and ${ }^{111}$ In-DOTAGA-cetuximab in our study. These results highlight the fact that immunoreactivity is not disturbed by DOTAGA incorporation and radiolabeling. In addition, the affinity of native cetuximab for HER 1 has been reported to range from 0.62 to $1.7 \mathrm{nM}$ $[38,39]$. In our study, ${ }^{111}$ In-DOTAGA-F $\left(\mathrm{ab}^{\prime}\right)_{2}$-cetuximab and ${ }^{111}$ In-DOTAGA-cetuximab displayed an affinity of 0.9 and $1.7 \mathrm{nM}$, respectively, thus demonstrating that $\mathrm{F}\left(\mathrm{ab}^{\prime}\right)_{2}$ fragments of cetuximab retain their affinity for HER1 after DOTAGA incorporation and radiolabeling. Therefore, 


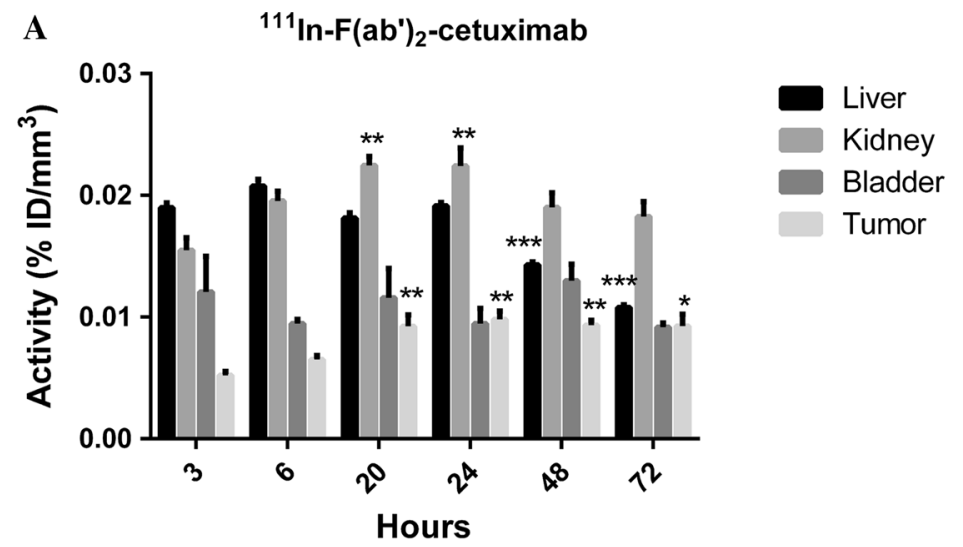

B
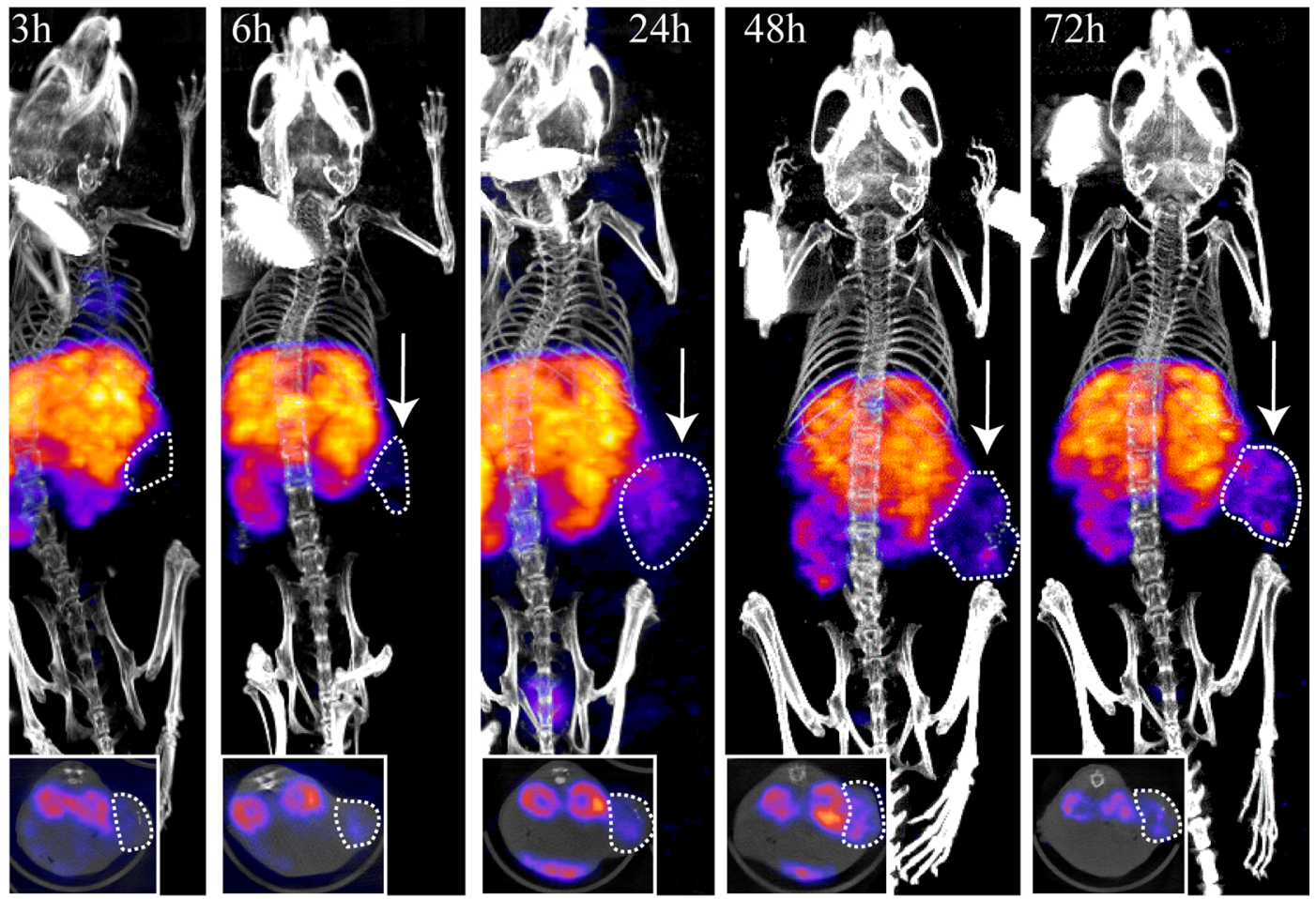

C

${ }^{111}$ In-(Fab) ${ }_{2}$-cetuximab

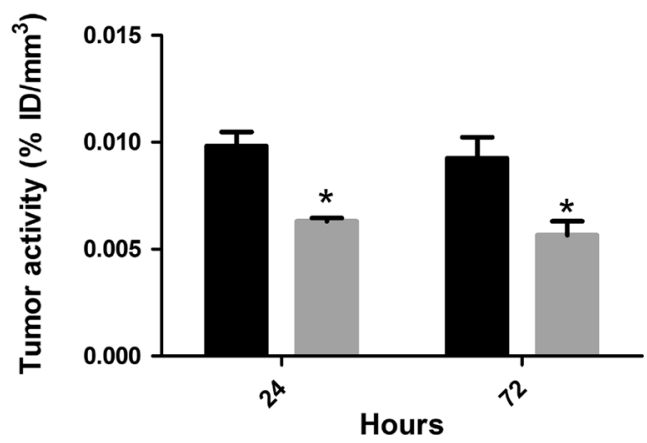

$\mathrm{F}\left(\mathrm{ab}^{\prime}\right)_{2}$-cetuximab represents a tool of interest for theranostic application by retaining high affinity for HER 1 and better pharmacokinetic properties than whole cetuximab for imaging/quantification of EGFR.
Another crucial issue in designing a radioimmunotherapeutic tool for theranostic use is the stability of the radionuclide in vitro and in vivo. Hence, the choice of the bifunctional chelating agent (BFC) used for radiolabeling is 
४Fig. 2 In vivo tumor specificity of ${ }^{111}$ In- DOTAGA-F $\left(\mathrm{ab}^{\prime}\right)_{2}$ cetuximab. a In vivo biodistribution of ${ }^{111} \operatorname{In}$-DOTAGA-F $\left(\mathrm{ab}^{\prime}\right)_{2}$ cetuximab in tumor (CR-LRB-014P cells) bearing balb/c nude mice at 3, 6, 20, 24, 48 and $72 \mathrm{~h}$ post injection. Liver, kidneys, bladder and tumor activity are expressed as $\% \mathrm{ID} / \mathrm{mm}^{3}$. Results are presented as mean \pm SEM; $n=3$, ** $p<0.01, * * * p<0.001$. b Representative SPECT pictures of ${ }^{111} \mathrm{In}$-DOTAGA-F $\left(\mathrm{ab}^{\prime}\right)_{2}$-cetuximab in tumor (CR-LRB-014P cells) bearing balb/c nude mice at 3, 6, 24, 48 and $72 \mathrm{~h}$ post injection. White arrows $/$ circle $=$ tumors. c Specific ${ }^{111}$ In-DOTAGA-F $\left(\mathrm{ab}^{\prime}\right)_{2}$-cetuximab tumor activity $\left(\% \mathrm{ID} / \mathrm{mm}^{3}\right)$ of tumor (CR-LRB-014P cells) bearing balb/c nude mice at 24 and $72 \mathrm{~h}$ post injection. Co-injection of ${ }^{111}$ In-DOTAGA-F $\left(\mathrm{ab}^{\prime}\right)_{2}$-cetuximab with excess $(2500 \mu \mathrm{g})$ cold- $\mathrm{F}\left(\mathrm{ab}^{\prime}\right)_{2}$-cetuximab was used to assess specificity. Results are presented as mean $\pm \mathrm{SEM} ; n=3,{ }^{*} p<0.05$

essential to minimize toxicity of the radionuclide to normal tissues. DTPA derivatives remain the most commonly used chelators for cetuximab radiolabeling in preclinical studies $[9,10]$ and in human $[40,41]$. However, macrocyclic chelators such as DOTA derivatives have been shown to form more stable antibody-conjugates in vitro and in vivo for a wide range of radionuclides including ${ }^{111} \mathrm{In}[20],{ }^{177} \mathrm{Lu}[14]$ and ${ }^{90} \mathrm{Y}[18,19]$. Importantly, Camera et al. [19] reported a lower bone uptake of ${ }^{90}$ Y-DOTA conjugates over ${ }^{90}$ Y-DTPA suggesting a better in vivo stability of DOTA conjugates limiting ${ }^{90} \mathrm{Y}$ toxicity. Similarly, the in vitro stability of ${ }^{177}$ Lu-DOTA conjugates over ${ }^{177}$ Lu-DTPA has been clearly demonstrated. Whether DOTA is also superior in vivo for ${ }^{177} \mathrm{Lu}$, it remains controversial. Milenic et al. [21] observed no significant differences between DOTA and DTPA conjugates, suggesting similar in vivo stabilities. On the contrary, Brouwers et al. [14] showed that uptake of ${ }^{177}$ Lu-DTPA was slightly higher in most tissues, including bone, and markedly higher in liver and spleen compared with ${ }^{177}$ Lu-DOTA suggesting a difference in in vivo stability between these two conjugates. In addition, a less complicated labeling procedure and an improved labeling efficiency often leads to a preference for DTPA as the chelator for radiolabeling with ${ }^{177} \mathrm{Lu}$ for radioimmunotherapy applications [21]. Indeed, the use of DOTA derivatives induces slower complex formation rates which can limit radiolabeling yields and efficiency. In addition, radiolabeling conditions to perform complexation often require extensive timeframe and high temperatures which are not acceptable for protein conjugates [42]. Nevertheless, our group developed and characterized in a previous study a DOTAGA-anhydride chelator as a powerful tool for bioconjugation [23]. DOTAGA is a DOTA derivative that leaves four acetate pendant arms intact and can be easily synthesized in good yield. Moreover, in the current study effective conjugation of DOTAGA-anhydride to cetuximab and $\mathrm{F}\left(\mathrm{ab}^{\prime}\right)_{2}$-cetuximab was achieved in conditions suitable for protein conjugates. In addition, DOTAGA conjugation did not disrupt cetuximab and $\mathrm{F}\left(\mathrm{ab}^{\prime}\right)_{2}$-cetuximab immunoreactivity/affinity and showed greater stability than corresponding DTPA conjugates as previously described for trastuzumab [23]. Moreover, ${ }^{177}$ Lu-DOTAGA complex has recently been shown to be highly stable in preclinical model of prostate cancer [43] and in patients showing high efficacy and low toxicity $[44,45]$. BM toxicity, including long-term haematological toxicities, has been reported in $11 \%$ of patients with metastatic neuroendocrine tumours treated with ${ }^{177}$ Lu-DOTA-Tyr3-octreotate $\left({ }^{177} \mathrm{Lu}\right.$-DOTATATE, [46]). In addition, $40 \%$ of patients with prostate cancer receiving ${ }^{177} \mathrm{Lu}$-DKFZ-617 showed hematotoxicity in a small cohort of 10 patients [47]. Interestingly, Baum et al. [44] reported no hematotoxicity of ${ }^{177}$ Lu-DOTAGA-PSMA complex in patients with prostate cancer with no worsening of anemia and leukocytopenia after therapy and no grade three or four hematologic toxicity in any of the patients. Thus, DOTAGA-anhydride chelator appears as a suitable tool for bioconjugation enabling a strong sequestration of radionuclides preventing their toxicity in vivo.

In the current study, we demonstrate that ${ }^{111} \mathrm{In}-\mathrm{F}\left(\mathrm{ab}^{\prime}\right)_{2^{-}}$ cetuximab specifically target colorectal tumors expressing HER1. Our results are comparable to what was found in previous publication mainly on head and neck cancer [11, $36,37]$. Surprisingly, the tumor targeting of ${ }^{111} \operatorname{In}-\mathrm{F}\left(\mathrm{ab}^{\prime}\right)_{2}$ cetuximab in colorectal tumors remains not well documented. Van Dijk et al. [11,37] demonstrated in a murine model of head and neck squamous cell carcinoma that ${ }^{111} \mathrm{In}-\mathrm{F}\left(\mathrm{ab}^{\prime}\right)_{2}$-cetuximab showed good tumor-to-background contrast on microSPECT imaging, allowing noninvasive assessment of EGFR expression in vivo. The same group also established that ${ }^{111} \mathrm{In}-\mathrm{F}\left(\mathrm{ab}^{\prime}\right)_{2}$-cetuximab was able to monitor the effects of EGFR inhibition or irradiation much better than ${ }^{18} \mathrm{~F}$-FDG PET confirming the added value of ${ }^{111} \mathrm{In}-\mathrm{F}\left(\mathrm{ab}^{\prime}\right)_{2}$-cetuximab to follow treatment efficacy [48]. In our study, ${ }^{111}$ In-DOTAGA-F $\left(\mathrm{ab}^{\prime}\right)_{2}$-cetuximab was used as a diagnostic tool for colorectal cancer to follow the efficacy of a HER 1 targeted therapy by the HSP90 inhibitor, 17-DMAG. HSP90 is a chaperon protein that has been demonstrated to bind and stabilize HER1 and whose inhibition causes a decrease in EGFR in cancer cells [27]. In addition to reducing membrane expression of EGFR, HSP90 inhibition significantly prevented tumor growth in head and neck squamous cell carcinoma animal models [27]. Interestingly, Spiegelberg et al. [49] recently showed by PET imaging with ${ }^{124}$ I-labeled cetuximab that HSP90 inhibition induced a decreased in EGFR expression in head and neck squamous cell carcinoma. Our results confirm, in a colorectal cancer model, that SPECT imaging of ${ }^{111} \mathrm{In}-\mathrm{F}\left(\mathrm{ab}^{\prime}\right)_{2}$-cetuximab is able to monitor EGFR downregulation and the prevention of tumor growth caused by HSP90 inhibition in vivo. Indeed, HSP90 inhibition induced a decrease in tumor uptake as well as a decrease in tumor growth compared to control mice. Interestingly, we demonstrate here that tumor volume physically measured with a clipper strongly correlated with tumor volumes assessed directly by SPECT imaging 

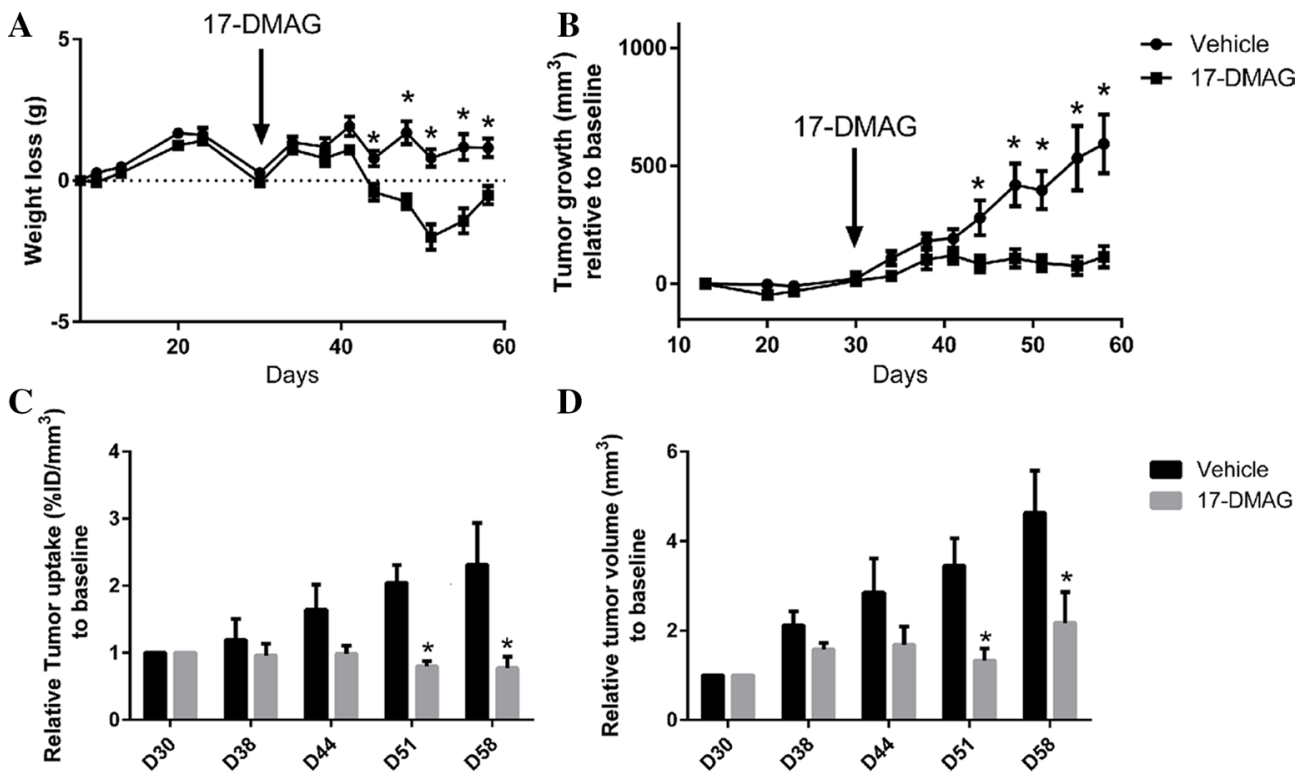

D
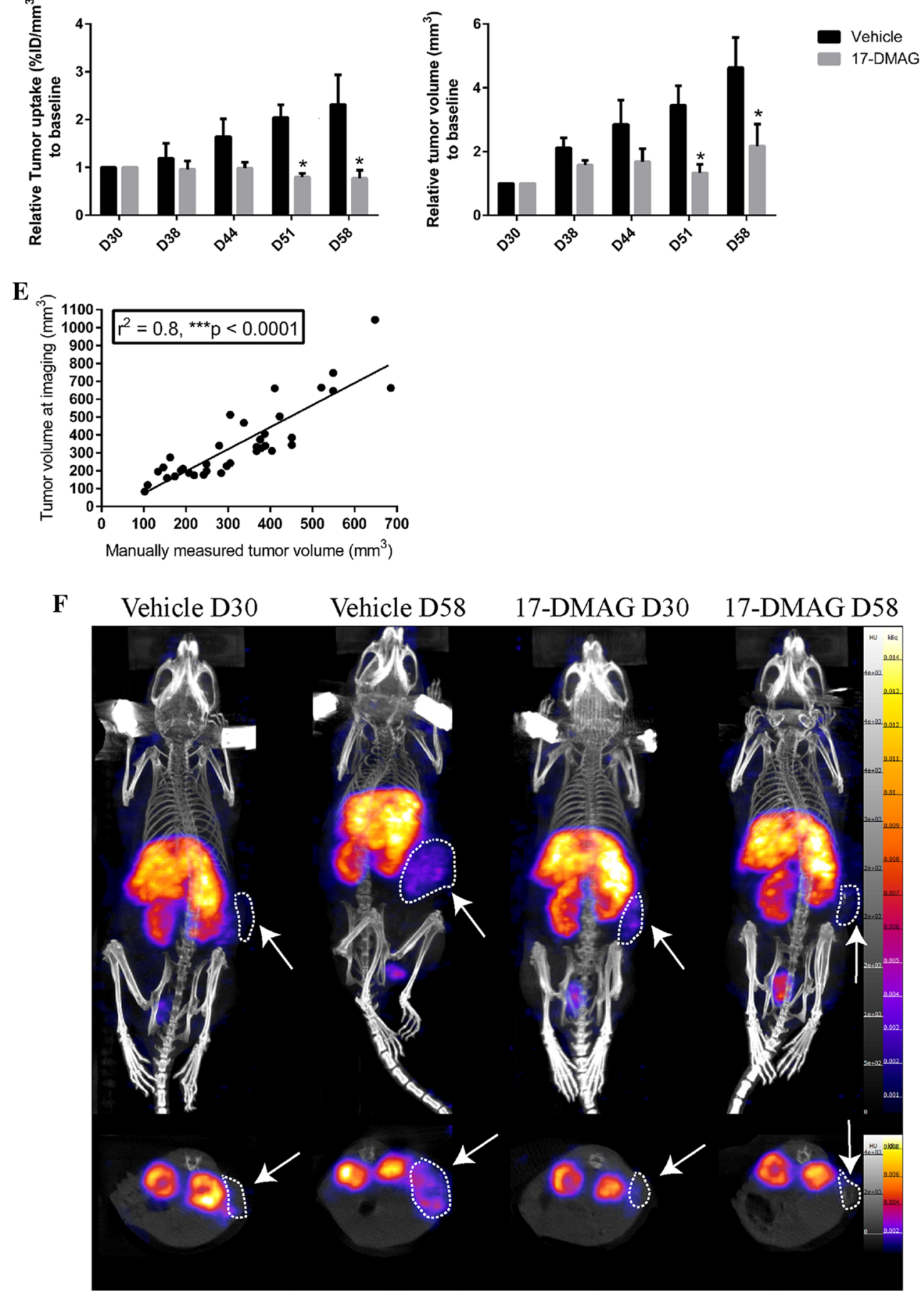
4 Fig. $3{ }^{111}$ In-DOTAGA-F $\left(\mathrm{ab}^{\prime}\right)_{2}$-cetuximab is a reliable tool to monitor 17-DMAG treatment efficacy. a Weight loss of $\mathrm{Balb} / \mathrm{c}$ nude mice receiving vehicle or 17-DMAG. CR-LRB-014P tumors were subcutaneously implanted at D0 and vehicle or 17-DMAG injections were performed starting at D30 (three times a week ip, $25 \mathrm{mg} / \mathrm{kg}$ ). Results are presented as mean \pm SEM; $n=10, * p<0.05$. b Tumor volume of $\mathrm{Balb} / \mathrm{c}$ nude mice receiving vehicle or 17-DMAG. CRLRB-014P tumors were subcutaneously implanted at D0 and vehicle or 17-DMAG injections were performed starting at D30 (three times a week ip, $25 \mathrm{mg} / \mathrm{kg}$ ). Tumor growth is expressed as a relative gain of volume from the first day when tumor was measurable (D10). Results are presented as mean \pm SEM; $n=10, * p<0.05$. c Relative ${ }^{111} \mathrm{In}$-DOTAGA-F $\left(\mathrm{ab}^{\prime}\right)_{2}$-cetuximab (imaging $24 \mathrm{~h} \mathrm{pi)} \mathrm{tumor} \mathrm{uptake} \mathrm{( \%}$ $\mathrm{ID} / \mathrm{mm}^{3}$ ) of Balb/c nude mice receiving vehicle or 17-DMAG. Tumor uptake is expressed relative to measures at D30 (start of 17-DMAG treatment). Results are presented as mean \pm SEM; $n=4, * p<0.05$. d Relative tumor volume $\left(\mathrm{mm}^{3}\right)$ measured by SPECT of Balb/c nude mice receiving vehicle or 17-DMAG. Tumor volume is expressed relative to measures at D30 (start of 17-DMAG treatment). Results are presented as mean $\pm \mathrm{SEM} ; n=4, * p<0.05$. e Correlation between tumor volumes measured manually and measured by SPECT/CT in $\mathrm{Balb} / \mathrm{c}$ nude mice receiving vehicle or 17-DMAG. f Representative SPECT/CT pictures of ${ }^{111}$ In-DOTAGA-F $\left(\mathrm{ab}^{\prime}\right)_{2}$-cetuximab in tumor bearing balb/c mice receiving vehicle or 17-DMAG at D30 (at treatment start = baseline) and D58 (4 weeks of treatment). White arrows/ circles highlight s.c. tumors

of ${ }^{111} \mathrm{In}-\mathrm{F}\left(\mathrm{ab}^{\prime}\right)_{2}$-cetuximab further validating the accuracy of imaging to follow tumor growth upon targeted therapy. Thus, tumor uptakes can be accurately expressed in regards to tumor volumes assessed directly by SPECT imaging in $\% \mathrm{ID} / \mathrm{mm}^{3}$. However, a statistical difference between 17-DMAG and control group was found from D44 when tumor volumes were manually measured, while significance was reached only from D51 when tumor volumes were measured by SPECT imaging. Due to its specificity, imaging should be more accurate than manual measurements but in our experiments only four mice per group were imaged while ten mice per group were used for manual measurements. This difference in the number of animal can explain the discrepancy between SPECT imaging and manual measurements in the time to reach significance.

One of the advantages of the ${ }^{111} \mathrm{In}-\mathrm{F}\left(\mathrm{ab}^{\prime}\right)_{2}$-cetuximab probe is the possibility to perform a radionuclide switch from ${ }^{111}$ In to ${ }^{177} \mathrm{Lu}$ to obtain a therapeutic tool ${ }^{177} \mathrm{Lu}-\mathrm{F}\left(\mathrm{ab}^{\prime}\right)_{2^{-}}$ cetuximab. $\beta^{-}$particles emitted by ${ }^{177} \mathrm{Lu}$ have a medium energy and a subsequent tissue penetration of $1.5 \mathrm{~mm}$ supporting its therapeutic use favored in treatment of small tumors while limiting irradiation of normal tissue [50]. Another asset of ${ }^{177} \mathrm{Lu}$, in comparison to other therapeutic radionuclide such as ${ }^{90} \mathrm{Y}$, is the low energy $\gamma$-emission that allows imaging. The combination of imaging and therapeutic properties makes ${ }^{177} \mathrm{Lu}$ a theranostic tool of choice increasingly used in preclinical and clinical studies [15, 44, 51, 52]. We demonstrate here that radioimmunotherapy with ${ }^{177} \mathrm{Lu}-\mathrm{F}\left(\mathrm{ab}^{\prime}\right)_{2}$-cetuximab significantly inhibited colorectal tumor growth when 4 and $8 \mathrm{MBq}$ are injected, but not significantly at $2 \mathrm{MBq}$. Our results confirm a previous study performed by Song et al. [16] with the whole form of cetuximab in a model of esophageal cancer. As mentioned above ${ }^{177} \mathrm{Lu}$ induces myelotoxicity. Interestingly, even if we did not evaluate hematologic toxicity, we noticed weight loss in mice receiving $4 \mathrm{MBq} 6$ days after injection, suggesting toxicity. Our results are in accordance with the findings of Fischer et al. [51] who evaluated experimentally the maximal tolerated dose of ${ }^{177} \mathrm{Lu}$ in nude mice bearing human ovarian cancer around $12 \mathrm{MBq}$. Nevertheless, even if $4 \mathrm{MBq}$ seemed to show early signs of toxicity (with no effect on survival), other doses ( 2 and $8 \mathrm{MBq}$ ) did not induce toxicity and showed efficacy in reducing tumor growth. Thus, a dose of $2 \mathrm{MBq}$ could be sufficient to achieve significant efficacy on tumor growth prevention without toxicity. The low energy and a low tissue penetration of ${ }^{177} \mathrm{Lu}$ favored its use for treatment in metastatic cancer. This could be of great interest in the treatment of peritoneal carcinomatosis of colorectal cancer origin in which EGFR upregulation has been demonstrated to be a factor of poor prognosis [53]. Cetuximab is already widely used for metastasized colorectal cancer but no clinical data on its specific use in peritoneal carcinomatosis is nowadays available [53]. ${ }^{177} \mathrm{Lu}-\mathrm{F}\left(\mathrm{ab}^{\prime}\right)_{2}$-cetuximab could allow peritoneal carcinomatosis early diagnosis by localizing metastasis formation and could also represent an important therapeutic strategy by specifically delivering ionizing radiation during early metastasis invasion.

\section{Conclusion}

To conclude, we demonstrate in the current paper that DOTAGA-F $\left(a b^{\prime}\right)_{2}$-cetuximab exhibits high in vivo and in vitro stability after radiolabeling with ${ }^{111}$ In and ${ }^{177} \mathrm{Lu}$. ${ }^{111}$ In-DOTAGA-F $\left(\mathrm{ab}^{\prime}\right)_{2}$-cetuximab is a reliable tool for SPECT imaging of colorectal cancer overexpressing HER1 and enables accurate therapy efficacy monitoring (e.g. antiHSP90 therapy). Moreover, the radionuclide switch from ${ }^{111}$ In to ${ }^{177} \mathrm{Lu}$ to form ${ }^{177} \mathrm{Lu}$-DOTAGA-F $\left(\mathrm{ab}^{\prime}\right)_{2}$-cetuximab allows radioimmunotherapy coupling therapeutic efficacy 

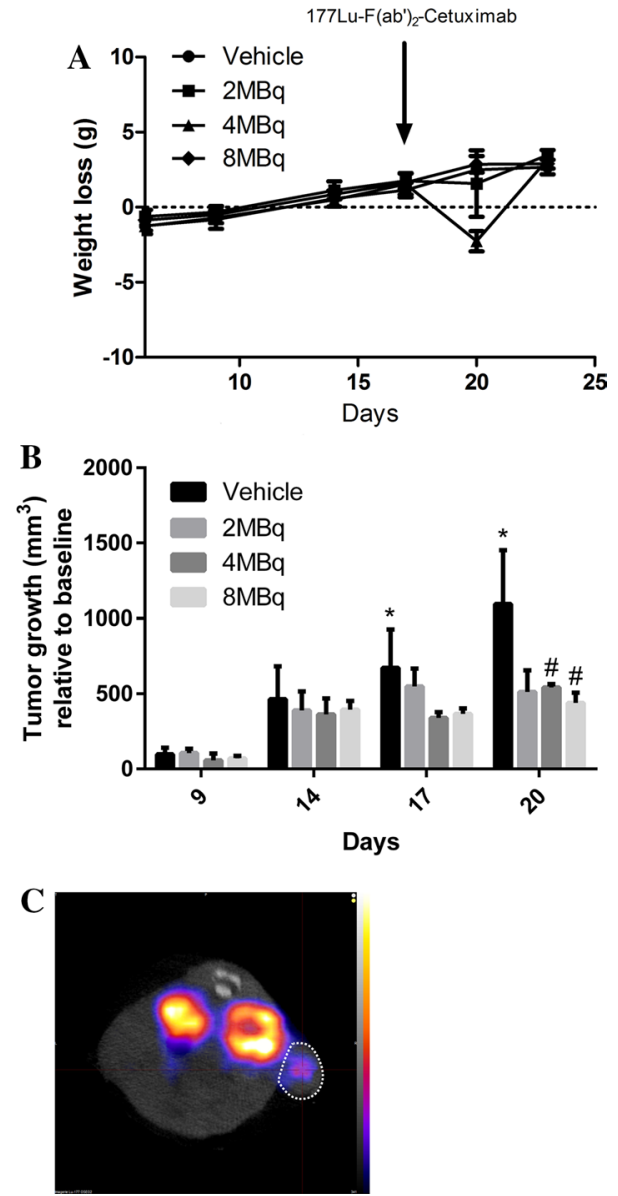

Fig. $4{ }^{177}$ Lu-DOTAGA-F $\left(\mathrm{ab}^{\prime}\right)_{2}$-cetuximab prevents tumor growth in vivo. a Weight loss of $\mathrm{Balb} / \mathrm{c}$ nude mice receiving vehicle or ${ }^{177} \mathrm{Lu}$-DOTAGA-F $\left(\mathrm{ab}^{\prime}\right)_{2}$-cetuximab (2, 4 or $\left.8 \mathrm{MBq}\right)$. A431 cells were subcutaneously implanted at D0 and vehicle or ${ }^{177}$ Lu-DOTAGA$\mathrm{F}\left(\mathrm{ab}^{\prime}\right)_{2}$-cetuximab injections were performed at D14. Results are presented as mean \pm SEM; $n=4, * * p<0.01$. b Tumor volume of $\mathrm{Balb} / \mathrm{c}$ nude mice receiving vehicle or ${ }^{177} \mathrm{Lu}$-DOTAGA-F $\left(\mathrm{ab}^{\prime}\right)_{2}$-cetuximab (2, 4 or $8 \mathrm{MBq}$ ). A431 cells were subcutaneously implanted at D0 and vehicle or ${ }^{177} \mathrm{Lu}$-DOTAGA-F $\left(\mathrm{ab}^{\prime}\right)_{2}$-cetuximab injections were performed at D14. Tumor growth is expressed as a relative gain of volume from the first day when tumor was measurable (D6). Results are presented as mean $\pm \mathrm{SEM} ; n=4$, ** $p<0.01$. c Representative image of ${ }^{177} \mathrm{Lu}$-DOTAGA-F $\left(\mathrm{ab}^{\prime}\right)_{2}$-cetuximab $(4 \mathrm{MBq})$ tumor activity in a tumor-bearing nude mice (D15). White circles $=$ tumors

and accurate imaging properties to treat and image HER1 expressing colorectal tumors.

Acknowledgements This work was performed within Pharm'image, a regional center of excellence in Pharmacoimaging. Support was provided by the French Government through the French National Research Agency (ANR) under the program "Investissements d'Avenir" (ANR10-EQPX-05-01/IMAPPI Equipex) and the CNRS, the "Université de Bourgogne" and the "Conseil Régional de Bourgogne" through the 3MIM integrated project ("Marquage de Molécules par les Métaux pour l'Imagerie Médicale"). This work is also part of the project "pharmacoimagerie et agents theranostiques", supported by the "Université de Bourgogne" and the "Conseil Régional de Bourgogne" through the "plan d'actions régional pour l'innovation (PARI)" and the European Union through the PO FEDER-FSE Bourgogne 2014/2020 programs. The authors would like to thank Laurence Collet for her great help in revising the manuscript.

Author contributions PSB, MM, FB and BC designed the study and wrote the protocol. LD and DV prepared the Fab fragment of cetuximab. CB, JMV and OR performed radiolabeling and in vitro validation. PSB, AO and JMV conducted the SPECT experiment. PSB, BC, FD, AC and FB analyzed the data. PSB, MM and $\mathrm{AC}$ wrote the first draft of the manuscript. FD, FB and $\mathrm{BC}$ mainly revised the manuscript. All authors read and approved the final manuscript.

Funding This study was funded by the French Government through the French National Research Agency (ANR) under the program "Investissements d'Avenir" (ANR-10EQPX-05-01/IMAPPI Equipex) and the CNRS, the "Université de Bourgogne" and the "Conseil Régional de Bourgogne" through the 3MIM integrated project ("Marquage de Molécules par les Métaux pour l'Imagerie Médicale"). This work is also part of the project "pharmacoimagerie et agents theranostiques", funded by the "Université de Bourgogne" and the "Conseil Régional de Bourgogne" through the "plan d'actions régional pour l'innovation (PARI)" and the European Union through the PO FEDER-FSE Bourgogne 2014/2020 programs.

\section{Compliance with ethical standards}

Conflict of interest All authors have declared that no competing interest exists.

Ethics approval All applicable international, national, and/or institutional guidelines for the care and use of animals were followed. All animal studies were sanctioned by the accredited Ethical committees (Oncomet $\mathrm{n}^{\circ} 91$ and C2ea Grand Campus $\mathrm{n}^{\circ} 105$ ) and were carried out in accordance to the legislation on the use of laboratory animals (directive 2010/63/EU). All procedures performed in studies involving human participants were in accordance with the ethical standards of the institutional and/or national research committee and with the 1964 Helsinki declaration and its later amendments or comparable ethical standards. Experiments were conducted following the European Union's animal care directive (86/609/EEC).

Informed consent Informed consent was obtained from all individual participants included in the study. Patient consent for the establishment of PDX (Patient-Derived Xenograft) models were developed by the CREMEC consortium and provided by Oncodesign ${ }^{\circledR}$ (Dijon, France).

Consent for publication Not applicable.

Open Access This article is distributed under the terms of the Creative Commons Attribution 4.0 International License (http://creativeco mmons.org/licenses/by/4.0/), which permits unrestricted use, distribution, and reproduction in any medium, provided you give appropriate 
credit to the original author(s) and the source, provide a link to the Creative Commons license, and indicate if changes were made.

\section{References}

1. Herbst RS. Review of epidermal growth factor receptor biology. Int J Radiat Oncol Biol Phys. 2004;59(2 Suppl):21-6. https://doi. org/10.1016/j.ijrobp.2003.11.041.

2. Humblet Y. Cetuximab: an $\operatorname{IgG}(1)$ monoclonal antibody for the treatment of epidermal growth factor receptor-expressing tumours. Expert Opin Pharmacother. 2004;5(7):1621-33. https://doi. org/10.1517/14656566.5.7.1621.

3. Bussink J, van der Kogel AJ, Kaanders JH. Activation of the $\mathrm{PI} 3-\mathrm{K} / \mathrm{AKT}$ pathway and implications for radioresistance mechanisms in head and neck cancer. Lancet Oncol. 2008;9(3):288-96. https://doi.org/10.1016/S1470-2045(08)70073-1.

4. Yamamoto VN, Thylur DS, Bauschard M, Schmale I, Sinha UK. Overcoming radioresistance in head and neck squamous cell carcinoma. Oral Oncol. 2016;63:44-51. https://doi.org/10.1016/j.oralo ncology.2016.11.002.

5. Bonner JA, Harari PM, Giralt J, Azarnia N, Shin DM, Cohen RB, et al. Radiotherapy plus cetuximab for squamous-cell carcinoma of the head and neck. N Engl j Med. 2006;354(6):567-78. https ://doi.org/10.1056/NEJMoa053422.

6. Petrelli F, Coinu A, Riboldi V, Borgonovo K, Ghilardi M, Cabiddu $\mathrm{M}$, et al. Concomitant platinum-based chemotherapy or cetuximab with radiotherapy for locally advanced head and neck cancer: a systematic review and meta-analysis of published studies. Oral Oncol. 2014;50(11):1041-8. https://doi.org/10.1016/j.oraloncolo gy.2014.08.005.

7. Ang KK, Zhang Q, Rosenthal DI, Nguyen-Tan PF, Sherman EJ, Weber RS, et al. Randomized phase III trial of concurrent accelerated radiation plus cisplatin with or without cetuximab for stage III to IV head and neck carcinoma: RTOG 0522. J clin oncol off J Am Soc Clin Oncol. 2014;32(27):2940-50. https://doi. org/10.1200/JCO.2013.53.5633.

8. James ML, Gambhir SS. A molecular imaging primer: modalities, imaging agents, and applications. Physiol Rev. 2012;92(2):897965. https://doi.org/10.1152/physrev.00049.2010.

9. Milenic DE, Wong KJ, Baidoo KE, Ray GL, Garmestani K, Williams M, et al. Cetuximab: preclinical evaluation of a monoclonal antibody targeting EGFR for radioimmunodiagnostic and radioimmunotherapeutic applications. Cancer Biother Radiopharm. 2008;23(5):619-31. https://doi.org/10.1089/cbr.2008.0493.

10. Huhtala T, Laakkonen P, Sallinen H, Yla-Herttuala S, Narvanen A. In vivo SPECT/CT imaging of human orthotopic ovarian carcinoma xenografts with ${ }^{111}$ In-labeled monoclonal antibodies. Nucl Med Biol. 2010;37(8):957-64. https://doi.org/10.1016/j.nucme dbio.2010.03.001.

11. van Dijk LK, Hoeben BA, Stegeman H, Kaanders JH, Franssen GM, Boerman OC, et al. ${ }^{111}$ In-cetuximab-F(ab') 2 SPECT imaging for quantification of accessible epidermal growth factor receptors (EGFR) in HNSCC xenografts. Radiother Oncol J Eur Soc Thera Radiol Oncol. 2013;108(3):484-8. https://doi.org/10.1016/j.radon c.2013.06.034.

12. Shih YH, Peng CL, Lee SY, Chiang PF, Yao CJ, Lin WJ, et al. ${ }^{111}$ In-cetuximab as a diagnostic agent by accessible epidermal growth factor (EGF) receptor targeting in human metastatic colorectal carcinoma. Oncotarget. 2015;6(18):16601-10. https://doi. org/10.18632/oncotarget.3968.

13. Lee SY, Hong YD, Kim HS, Choi SJ. Synthesis and application of a novel cysteine-based DTPA-NCS for targeted radioimmunotherapy. Nucl Med Biol. 2013;40(3):424-9. https://doi.org/10.1016/j. nucmedbio.2012.12.007.
14. Brouwers AH, van Eerd JE, Frielink C, Oosterwijk E, Oyen WJ, Corstens FH, et al. Optimization of radioimmunotherapy of renal cell carcinoma: labeling of monoclonal antibody cG250 with ${ }^{131} \mathrm{I},{ }^{90} \mathrm{Y},{ }^{177} \mathrm{Lu}$, or ${ }^{186} \mathrm{Re}$. J Nucl Med Off Publ Soc Nucl Med. 2004;45(2):327-37.

15. Liu Z, Ma T, Liu H, Jin Z, Sun X, Zhao H, et al. ${ }^{177}$ Lu-labeled antibodies for EGFR-targeted SPECT/CT imaging and radioimmunotherapy in a preclinical head and neck carcinoma model. Mol Pharm. 2014;11(3):800-7. https://doi.org/10.1021/mp400 5047.

16. Song IH, Lee TS, Park YS, Lee JS, Lee BC, Moon BS, et al. Immuno-PET Imaging and Radioimmunotherapy of ${ }^{64} \mathrm{Cu}$ ${ }^{177}$ Lu-Labeled Anti-EGFR Antibody in Esophageal Squamous Cell Carcinoma Model. J Nucl Med Off Publ Soc Nucl Med. 2016;57(7):1105-11. https://doi.org/10.2967/jnumed.115.167155.

17. Perk LR, Visser GW, Vosjan MJ, Stigter-van Walsum M, Tijink $\mathrm{BM}$, Leemans CR, et al. ${ }^{89} \mathrm{Zr}$ as a PET surrogate radioisotope for scouting biodistribution of the therapeutic radiometals ${ }^{90} \mathrm{Y}$ and ${ }^{177} \mathrm{Lu}$ in tumor-bearing nude mice after coupling to the internalizing antibody cetuximab. J Nucl Med Off Publ Soc Nucl Med. 2005;46(11):1898-906.

18. Harrison A, Walker CA, Parker D, Jankowski KJ, Cox JP, Craig $\mathrm{AS}$, et al. The in vivo release of ${ }^{90} \mathrm{Y}$ from cyclic and acyclic ligand-antibody conjugates. Int J Radiat Appl Instrum Part B Nucl Med Biol. 1991;18(5):469-76.

19. Camera L, Kinuya S, Garmestani K, Wu C, Brechbiel MW, Pai $\mathrm{LH}$, et al. Evaluation of the serum stability and in vivo biodistribution of CHX-DTPA and other ligands for yttrium labeling of monoclonal antibodies. J Nucl Med Off Publ Soc Nucl Med. 1994;35(5):882-9.

20. Smith-Jones PM, Vallabahajosula S, Goldsmith SJ, Navarro V, Hunter CJ, Bastidas D, et al. In vitro characterization of radiolabeled monoclonal antibodies specific for the extracellular domain of prostate-specific membrane antigen. Can Res. 2000;60(18):5237-43.

21. Milenic DE, Garmestani K, Chappell LL, Dadachova E, Yordanov A, Ma D, et al. In vivo comparison of macrocyclic and acyclic ligands for radiolabeling of monoclonal antibodies with ${ }^{177} \mathrm{Lu}$ for radioimmunotherapeutic applications. Nucl Med Biol. 2002;29(4):431-42.

22. Bernhard C, Moreau M, Lhenry D, Goze C, Boschetti F, Rousselin $\mathrm{Y}$, et al. DOTAGA-anhydride: a valuable building block for the preparation of DOTA-like chelating agents. Chemistry. 2012;18(25):7834-41. https://doi.org/10.1002/chem.201200132.

23. Moreau M, Raguin O, Vrigneaud JM, Collin B, Bernhard C, Tizon $\mathrm{X}$, et al. DOTAGA-trastuzumab. a new antibody conjugate targeting HER2/Neu antigen for diagnostic purposes. Bioconjug Chem. 2012;23(6):1181-8. https://doi.org/10.1021/bc200680x.

24. Adams GP, Schier R, McCall AM, Simmons HH, Horak EM, Alpaugh RK, et al. High affinity restricts the localization and tumor penetration of single-chain $\mathrm{fv}$ antibody molecules. Can Res. 2001;61(12):4750-5.

25. Lunt SJ, Chaudary N, Hill RP. The tumor microenvironment and metastatic disease. Clin Exp Metas. 2009;26(1):19-34. https://doi. org/10.1007/s10585-008-9182-2.

26. Wong KJ, Baidoo KE, Nayak TK, Garmestani K, Brechbiel MW, Milenic DE. In Vitro and In Vivo pre-clinical analysis of a F(ab' $)^{2}$ fragment of panitumumab for molecular imaging and therapy of HER1 positive cancers. EJNMMI Res. 2011;1(1):1. https://doi. org/10.1186/2191-219x-1-1.

27. Ahsan A, Ramanand SG, Whitehead C, Hiniker SM, Rehemtulla A, Pratt WB, et al. Wild-type EGFR is stabilized by direct interaction with HSP90 in cancer cells and tumors. Neoplasia. 2012;14(8):670-7.

28. Zhang F, Wang S, Yin L, Yang Y, Guan Y, Wang W, et al. Quantification of epidermal growth factor receptor expression level 
and binding kinetics on cell surfaces by surface plasmon resonance imaging. Anal Chem. 2015;87(19):9960-5. https://doi. org/10.1021/acs.analchem.5b02572.

29. Marmol I, Sanchez-de-Diego C, Pradilla Dieste A, Cerrada E, Rodriguez Yoldi MJ. Colorectal carcinoma: a general overview and future perspectives in colorectal cancer. Int J Mol Sci. 2017;18(1):197. https://doi.org/10.3390/ijms18010197.

30. Curtin JC. Novel drug discovery opportunities for colorectal cancer. Expert Opin Drug Discov. 2013;8(9):1153-64. https://doi. org/10.1517/17460441.2013.807249.

31. Siegel R, Naishadham D, Jemal A. Cancer statistics, 2013. CA Cancer J Clin. 2013;63(1):11-30. https://doi.org/10.3322/ caac. 21166.

32. Khelwatty SA, Essapen S, Seddon AM, Modjtahedi H. Prognostic significance and targeting of HER family in colorectal cancer. Front Biosci. 2013;18:394-421.

33. Harding J, Burtness B. Cetuximab: an epidermal growth factor receptor chemeric human-murine monoclonal antibody. Drugs Today. 2005;41(2):107-27. https://doi.org/10.1358/ dot.2005.41.2.882662.

34. Sihver W, Pietzsch J, Krause M, Baumann M, Steinbach J, Pietzsch HJ. Radiolabeled cetuximab conjugates for EGFR targeted cancer diagnostics and therapy. Pharmaceuticals. 2014;7(3):31138. https://doi.org/10.3390/ph7030311.

35. Covell DG, Barbet J, Holton OD, Black CD, Parker RJ, Weinstein $\mathrm{JN}$. Pharmacokinetics of monoclonal immunoglobulin $\mathrm{G}_{1}, \mathrm{~F}(\mathrm{ab})_{2}$, and Fab' in mice. Can Res. 1986;46(8):3969-78.

36. van Dijk LK, Yim CB, Franssen GM, Kaanders JH, Rajander J, Solin O, et al. PET of EGFR with ${ }^{64} \mathrm{Cu}$-cetuximab-F(ab' $)^{2}$ in mice with head and neck squamous cell carcinoma xenografts. Contrast Media Mol Imaging. 2016;11(1):65-70. https://doi.org/10.1002/ cmmi.1659.

37. van Dijk LK, Hoeben BA, Kaanders JH, Franssen GM, Boerman OC, Bussink J. Imaging of epidermal growth factor receptor expression in head and neck cancer with SPECT/CT and ${ }^{111} \mathrm{In}-$ labeled cetuximab-F(ab') ${ }_{2}$. J Nucl Med Off Publ Soc Nucl Med. 2013;54(12):2118-24. https://doi.org/10.2967/jnumed.113.123612.

38. Kim DH, Zhou K, Kim DK, Park S, Noh J, Kwon Y, et al. Analysis of interactions between the epidermal growth Factor receptor and soluble ligands on the basis of single-molecule diffusivity in the membrane of living cells. Angew Chem. 2015;54(24):7028 32. https://doi.org/10.1002/anie.201500871.

39. Haeder M, Rotsch M, Bepler G, Hennig C, Havemann K, Heimann $\mathrm{B}$, et al. Epidermal growth factor receptor expression in human lung cancer cell lines. Can Res. 1988;48(5):1132-6.

40. Yoshida H, Mochizuki M, Kainouchi M, Ishida T, Sakata K, Yokoyama S, et al. Clinical application of indium-111 antimyosin antibody and thallium-201 dual nuclide single photon emission computed tomography in acute myocardial infarction. Ann Nucl Med. 1991;5(1):41-6.

41. Divgi CR, Welt S, Kris M, Real FX, Yeh SD, Gralla R, et al. Phase I and imaging trial of indium 111-labeled anti-epidermal growth factor receptor monoclonal antibody 225 in patients with squamous cell lung carcinoma. J Natl Cancer Inst. 1991;83(2):97-104.

42. Brechbiel MW. Bifunctional chelates for metal nuclides. The Q J Nucl Med Mol Imaging Official Publ Ital Assoc Nucl Med. 2008;52(2):166-73.
43. Weineisen M, Simecek J, Schottelius M, Schwaiger M, Wester HJ. Synthesis and preclinical evaluation of DOTAGA-conjugated PSMA ligands for functional imaging and endoradiotherapy of prostate cancer. EJNMMI Res. 2014;4(1):63. https://doi. org/10.1186/s13550-014-0063-1.

44. Baum RP, Kulkarni HR, Schuchardt C, Singh A, Wirtz M, Wiessalla $\mathrm{S}$, et al. ${ }^{177} \mathrm{Lu}$-labeled prostate-specific membrane antigen radioligand therapy of metastatic castration-resistant prostate cancer: safety and efficacy. J Nucl Med Off Publ Soc Nucl Med. 2016;57(7):1006-13. https://doi.org/10.2967/jnumed.115.168443.

45. Weineisen M, Schottelius M, Simecek J, Baum RP, Yildiz A, Beykan S, et al. ${ }^{68} \mathrm{Ga}$ - and ${ }^{177} \mathrm{Lu}$-labeled PSMA I\&T: optimization of a PSMA-targeted theranostic concept and first proofof-concept human studies. J Nucl Med Off Publ Soc Nucl Med. 2015;56(8):1169-76. https://doi.org/10.2967/jnumed.115.158550.

46. Bergsma H, Konijnenberg MW, Kam BL, Teunissen JJ, Kooij PP, de Herder WW, et al. Subacute haematotoxicity after PRRT with ${ }^{177} \mathrm{Lu}$-DOTA-octreotate: prognostic factors, incidence and course. Eur J Nucl Med Mol Imaging. 2016;43(3):453-63. https://doi. org/10.1007/s00259-015-3193-4.

47. Ahmadzadehfar H, Rahbar K, Kurpig S, Bogemann M, Claesener M, Eppard E, et al. Early side effects and first results of radioligand therapy with ${ }^{177} \mathrm{Lu}$-DKFZ-617 PSMA of castrate-resistant metastatic prostate cancer: a two-centre study. EJNMMI Res. 2015;5(1):114. https://doi.org/10.1186/s13550-015-0114-2.

48. van Dijk LK, Boerman OC, Franssen GM, Kaanders JH, Bussink J. ${ }^{111}$ In-cetuximab-F(ab') ${ }_{2}$ SPECT and ${ }^{18}$ F-FDG PET for prediction and response monitoring of combined-modality treatment of human head and neck carcinomas in a mouse model. J Nucl Med Off Publ Soc Nucl Med. 2015;56(2):287-92. https://doi. org/10.2967/jnumed.114.148296.

49. Spiegelberg D, Mortensen AC, Selvaraju RK, Eriksson O, Stenerlow B, Nestor M. Molecular imaging of EGFR and CD44v6 for prediction and response monitoring of HSP90 inhibition in an in vivo squamous cell carcinoma model. Eur J Nucl Med Mol Imaging. 2016;43(5):974-82. https://doi.org/10.1007/s0025 9-015-3260-x.

50. Borjesson PK, Postema EJ, de Bree R, Roos JC, Leemans CR, Kairemo KJ, et al. Radioimmunodetection and radioimmunotherapy of head and neck cancer. Oral Oncol. 2004;40(8):761-72. https://doi.org/10.1016/j.oraloncology.2003.11.009.

51. Fischer E, Grunberg J, Cohrs S, Hohn A, Waldner-Knogler K, Jeger S, et al. L1-CAM-targeted antibody therapy and ${ }^{177}$ Lu-radioimmunotherapy of disseminated ovarian cancer. Int J Cancer. 2012;130(11):2715-21. https://doi.org/10.1002/ijc.26321.

52. Tagawa ST, Milowsky MI, Morris M, Vallabhajosula S, Christos $\mathrm{P}$, Akhtar NH, et al. Phase II study of Lutetium-177-labeled antiprostate-specific membrane antigen monoclonal antibody J591 for metastatic castration-resistant prostate cancer. Clin Cancer Res Off J Am Assoc Cancer Res. 2013;19(18):5182-91. https://doi. org/10.1158/1078-0432.CCR-13-0231.

53. de Cuba EM, Kwakman R, van Egmond M, Bosch LJ, Bonjer HJ, Meijer GA, et al. Understanding molecular mechanisms in peritoneal dissemination of colorectal cancer: future possibilities for personalised treatment by use of biomarkers. Virchows Archiv Int J Pathol. 2012;461(3):231-43. https://doi.org/10.1007/s0042 8-012-1287-y. 